Oriental Journal of Medicine and Pharmacology

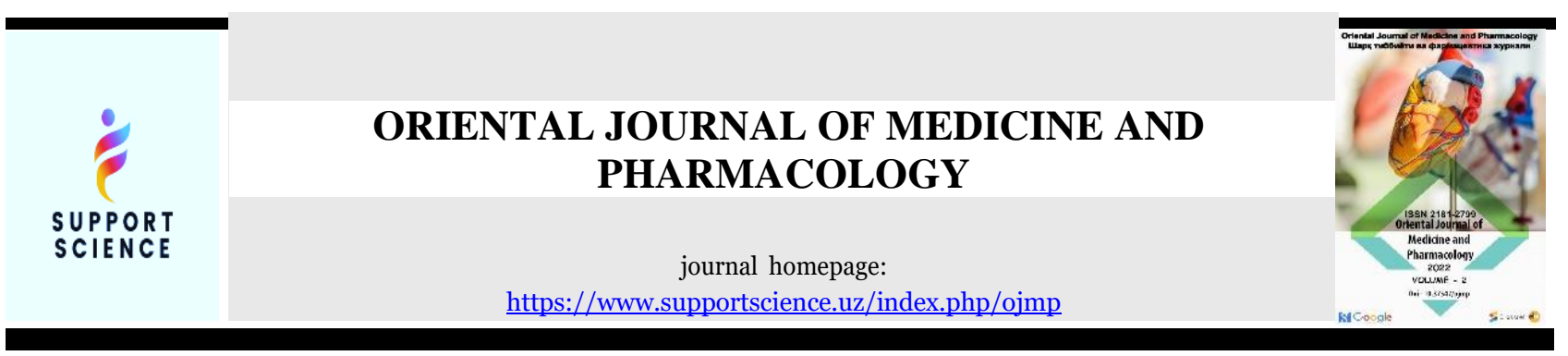

\title{
RESULTS OF A MORPHOLOGICAL STUDY OF MUCORMYCOSIS COMPLICATIONS OF THE MAXILLOFACIAL AREA AFTER COVID-19
}

\author{
Sh.A. Boymuradov \\ Doctor of Philosophy in Medicine, Tashkent Medical Academy, Uzbekistan
}

Yo.Kh. Kurbonov

Doctor of Philosophy in Medicine, Tashkent Medical Academy, Uzbekistan

\section{J.A. Djuraev}

Doctor of Philosophy in Medicine, Tashkent Medical Academy, Uzbekistan

A.J. Botirov

Doctor of Philosophy in Medicine, Tashkent Medical Academy, Uzbekistan

\section{ABOUT ARTICLE}

Key words: mucromycosis, necrosis, fungus, face-jaw area.

Received: 04.01.22

Accepted: 10.01 .22

Published: 15.01 .22
Abstract: This article presents the results of a morphological examination of facial mucosa complications after COVID-19. Infection of patients with COVID-19 with mucormycosis in the oral cavity is manifested in the form of discoloration of the mucous membrane in the area of the palate, swelling, ulcers, necrotic foci on the palate, hard palate and jaw bones, and the dark surface of the bone surface (Brandao et al ., 2020). It should be borne in mind that the recent emergence and development of mucormycosis with COVID-19 is not considered to be fully interrelated, but sufficient causes and conditions for the occurrence of this process during the pandemic, as well as the presence of somatic comorbidities, chronic microbial foci in patients. 
Ш.А.Боймурадов, Ё.Х.Курбонов, Ж.А.Джсураев, А.Ж. Ботиров

Тоикент тиббиёт академияси

МАҚОЛА ХАҚИДА

Калит сўзлар: мукромикоз, некроз, замбуруғ, юз-жағ сохаси.
Аннотация: Ушбу мақолада COVID19дан кейинги юз-жағ сохаси мукормикоз асоратлари морфологик текширув натижалари келтирилган. COVID-19 билан оғриган беморларни оғиз бўшлиғида мукормикоз билан зарарланиши танглай сохасида шиллиқ қаватини рангини турли кўринишда ўзгариши, шиш, яра, танглайда юза некротик ўчоқлар, қаттиқ танглай ва жағ суякларини ялонғочланиши ва суяк юзасининг қорамтир юзаси ғадир-будир кўринишида намоён бўлади (Brandao et al., 2020). Шуни инобатга олиш керакки, мукормикознинг яқинда пайдо бўлиши ва COVID-19 билан бирга ривожланиши бу касалликларни бир бирига тўлиқ боғлик деб хисобланмасада, пандемия даврида бу жараённи келиб чиқишига етарлича сабаб ва шароитлар хамда беморларда соматик хамрох касалликлар, сурункали микроб ўчоқларини бўлиши мукормикозни ривожланишига туртки бўлади. 


\section{РЕЗУЛЬТАТЫ МОРФОЛОГИЧЕСКОГО ИССЛЕДОВАНИЯ ОСЛОЖНЕНИЙ} МУКОРМИКОЗА ЧЕЛЮСТНО-ЛИЦЕВОЙ ОБЛАСТИ ПОСЛЕ COVID-19

\section{Ш.А. Боймурадов, Э.Х. Курбонов, Ж.А. Дюсураев, А.Ж. Ботиров}

Ташкентская медицинская академия

\begin{tabular}{|c|c|}
\hline \multicolumn{2}{|c|}{ О СТАТЬЕ } \\
\hline $\begin{array}{c}\text { Ключевые слова: } \\
\text { мукромикоз, } \\
\text { некроз, грибок, челюстно-лицевая область. }\end{array}$ & $\begin{array}{l}\text { Аннотация: В статье представлены } \\
\text { результаты морфологического исследова- } \\
\text { ния осложнений мукормикоза лицевой- } \\
\text { челюстной области после COVID-19. } \\
\text { Заражение больных } \\
\text { мукормикозом полости рта проявляется в } \\
\text { виде изменения цвета слизистой оболочки } \\
\text { в области неба, отека, язв, некротических } \\
\text { очагов на небе, твердом небе и костях } \\
\text { челюстей, а также темная поверхность } \\
\text { поверхности кости (Вrandaо еt аl., 2020). } \\
\text { Следует иметь в виду, что недавнее } \\
\text { возникновение и развитие мукормикоза } \\
\text { при СОVID-19 считается не полностью } \\
\text { взаимосвязанными, а достаточными } \\
\text { причинами и условиями возникновения } \\
\text { этого процесса в период пандемии, а также } \\
\text { наличием сопутствующих соматических } \\
\text { заболеваний, хронические микробные } \\
\text { очаги у больных. }\end{array}$ \\
\hline
\end{tabular}

\section{І. КИРИШ}

Мукормикоз - нисбатан кам учрайдиган, аммо хаёт учун хавфли бўлган инвазив замбуруғли инфекция бўлиб, уни Mucorales тартибининг турли авлодлари ва турлари кўзғатади, Mucoraceae нинг олтита оиласи энг кенг тарқалган бўлиб, иммунитети кучсиз беморларни зарарлайди [1]. Мукормикоз кўпинча хўжайин организми химоясида жиддий нуқсонлар ва қон зардобида темир моддаси юқори бўлган беморларда учрайди, аммо иммунокомпетент хўжайинни спорадик зарарлаши хам мумкин [1-3]. Мукормикоз, шунингдек, гематологик хавфли ўсмалар бўлган, аллоген ўзак хужайралар трансплантацияси ўтказилган ва қандли диабет билан оғриган беморлар орасида мухим касаллик хисобланади [4]. Тарихан, стероидларни нотўғри ишлатиш ушбу инвазив замбуруғли инфекциянинг ривожланиши билан боғлиқ бўлган, айниқса, агар у юқоридаги хавф омилларидан бири билан боғлиқ бўлса. Бундан ташқари, стероидларни нотўғри ишлатиш мукормикоз ва аспергиллоз каби ёндош инвазив замбуруғли инфекцияларни келтириб чиқариши мумкин [9].

2019 йил коронавирус касаллиги (OVID-19) пандемиясининг бошида 2020 йилда коронавирус 2 (SARS-CoV-2$)$ келтириб чиқарган оғир ўткир респиратор синдромли инфекцияга қарши курашиш учун самарали терапевтик ёндашувларни ишлаб чиқиш ва 
қайта йўналтириш зарурати кўплаб дори вариантларини қайта кўриб чиқишга сабаб бўлди. Кўплаб клиник синовлар ишлаб чиқилди, жумладан, оғир клиник холатларда стероидларнинг роли бахоланди. Ушбу тадқиқотлардан бири, RECOVERY тадқиқоти, ўпканинг инвазив механик вентиляциясини ёки фақат кислород терапиясини олганлар орасида рандомизациядан сўнг 28-кунга келиб, ўлимнинг сезиларли даражада камайишини кўрсатди [10]. Афсуски, бошқа дорилар, масалан хлорохин каби ушбу дорилар хам клиник сценарийларда нотўғри ишлатилган, фойда кам бўлган ёки умуман бўлмаган $[1-4,14]$. Эхтимол, стероидларни нотўғри қўллаш билан боғлиқ бўлган, хозирда COVID-19 билан ассоциацияланган мукормикоз (CAM) сифатида каталогга киритилган COVID-19 билан оғриган беморлар орасида мукормикозларнинг кўпайиб бораётгани дунёнинг кўплаб мамлакатларида [5], шу жумладан, Бразилия ва Мексика каби Лотин Америка давлатларида хам қайд этилган [6].

Кўпгина хабарлар ва ўлимлар холати бурун-оғиз ва ўпка инфекциялари билан боғлиқ бўлса-да, бизга маълумки, адабиётларда гангреноз суяк некрози билан асоратланган бурун-оғиз САМнинг бошқа хеч қандай холатлари қайд этилмаган.

Журналдаги [7] биринчи нашримиздан сўнг бир нечта САМ холатлари хақида хабарлар берилди. Биз тизимли шархимизни (PubMed ва Embase маълумотлар базалари) 2021 йил 21 июнгача куйидаги атамаларни: (“COVID” ёки “SARS-CoV-2” ёки

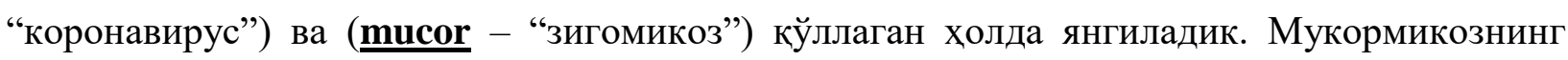
фақат микробиологик ёки гистологик жихатдан тасдиқланган холатлари, тақризланган нашрларда ёритилганлари киритилди [11]. COVID-19 тасдиқлангандан сўнг етти кун ўтгач ташхисланган мукормикозни (максимал 3 ойгача) биз “кечки САМ” деб хисобладик. Қолган холатларни, яъни мукормикоз COVID-19 билан бир вақтнинг ўзида ёки ундан кейин етти кун ичида ташхисланган холатлар “эрта САМ” деб хисобланди. Биз тахлил қилиш учун бемордан алохида маълумотларни сўрадик, маълумотлар мавжуд бўлмаганда эса, истисно қилишдан олдин қўшимча маълумот олиш учун тегишли муаллиф билан боғландик. Биз нашрлардан қуйидаги маълумотларни: муаллиф ва нашр этилган мамлакат, (11) субъектларнинг ёши ва жинси, мойил омиллар (қаттиқ органлар трансплантацияси, гемапоэтик ўзак хужайралари трансплантацияси, гематологик хавфли ўсмалар, қандли диабет ва бошқалар), COVID-19ни даволаш тафсилотлари, шу жумладан гипоксемиянинг мавжудлиги, ўпка сунъий вентиляцияси зарурати, симптомлар юзага келгандан ёки COVID-19 тасдиқлангандан бошлаб мукормикоз ташхиси қўйилишигача бўлган вақт, COVID-19ни даволаш учун ишлатиладиган глюкокортикоидларнинг ва бошқа ишлатиладиган иммунодепрессантларнинг дозаси ва қабул қилиш давомийлиги, [12] мукормикоз хақида батафсил маълумотлар, жумладан зарарланиш жойи, таклиф 
қилинган даволашнинг тиббий (амфотерицин В, изавуконазол, позаконазол ёки уларнинг комбинацияси) ва жаррохлик муолажалари хақида маълумотлар [13] ва ЎАБ дан ўлим кўрсаткичларини олдик.

II. ТАДҚИКОТНИНГ МАҚСАДИ: COVID-19 ўтказган ва юз-жағ сохаси мукормикоз билан асоратланган беморларда морфологик тадқиқот ўтказиш.

III. ТАДҚИҚОТ МАТЕРИАЛ ВА УСУЛЛАРИ: 2019-2021-йилларда Тошкент тиббиёт академияси кўп тармоқли клиникасининг COVID дан кейинги марказида COVID19 инфекцияси ва унинг юз-жағ сохасидаги йирингли-некротик асоратлари билан даволанган 118 нафар беморни комплекс текширувдан ўтказдик ва даволадик. Ўрганилаётган холат сифатида юз-жағ сохасида йирингли-некротик жараёнлар бўлган беморлардаги ярали жараённинг клиник кўрсаткичлари ва қондаги иммун химоя омиллари кўриб чиқилди. Ташқи кўрикда ва махаллий холатни аниқлашда анатомик сохаларнинг шишиши хисобига юз ва бўйин конфигурациясидаги ўзгаришларнинг мавжудлиги аниқланди. Шишган сохадаги терининг ранги (тана ранги, гиперемия) визуал (кўз орқали кўриш билан) бахоланди. Палпацияда инфилтратнинг ўлчами, оғриқнинг борлиги, терининг таранглиги, йирингли ўчоқларнинг мавжудлиги аниқланди. Винсент симптомини аниқлаш ўтказилди. Оғизни очиш даражаси, яллиғланиш контрактурасининг намоён бўлиши ва оғриқлар аниқланди.

Барча беморлар 2та гурухга бўлинди (1-расм).

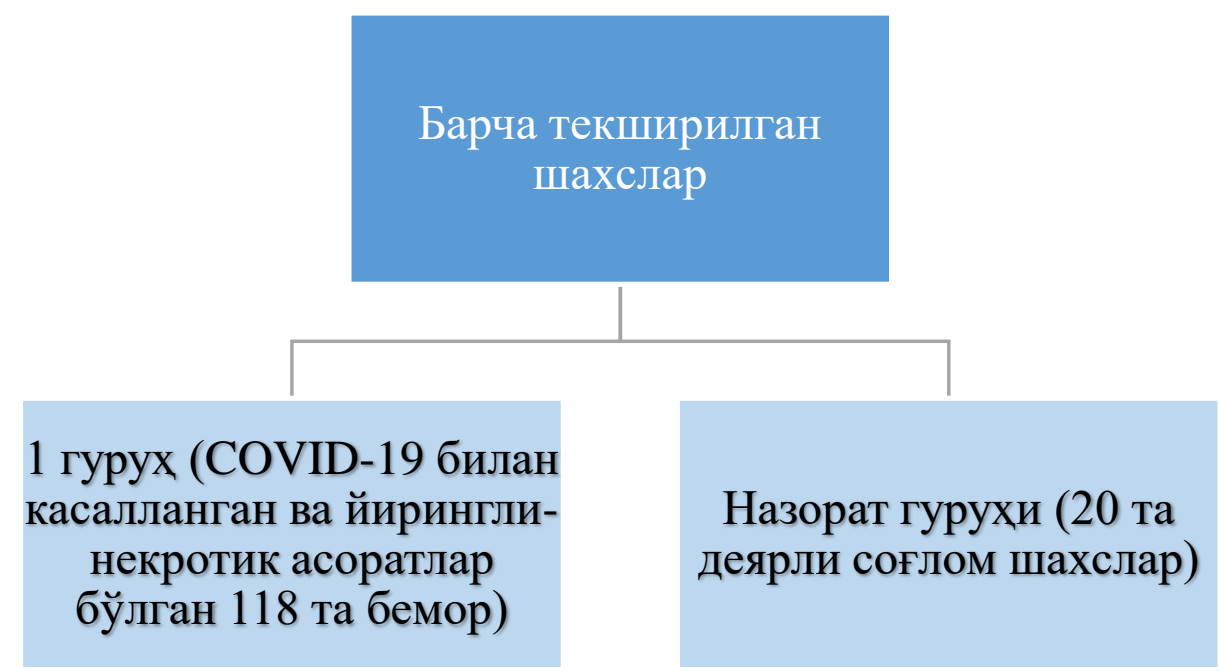

COVID-19 билан касалланган беморлар юзида йирингли-некротик жарохатларнинг турли шаклларини ва кечишини аниқлаш, шунингдек даволаш усулларини яхшилаш мақсадида тепа юз-жағ, бурун шиллиқ қавати ва бурун олди синусларидан олинган материалларни морфологик тадқиқ қилдик. Олинган натижаларга кўра беморлар қуйидаги гурухларга бўлинди; биринчиси - мукормикоз билан касалланган беморлар, иккинчиси синус тромбоз билан касалланган беморлар. FESS (Functional Endoscopic Sinus Surgery. 
Funktsional endoskopik sinus operatsiyasi bu minimal invaziv protsedura bo'lib, u paranasal sinuslarning burun drenaj yo'llarini kattalashtirish uchun burun endoskoplari yordamida sinusli ventilyatsiyani yaxshilaydi va mahalliy dorilarga ruxsat beradi. Functional Endoscopic Sinus Surgery is a minimally invasive procedure which uses nasal endoscopes to enlarge the nasal drainage pathways of the paranasal sinuses to improve sinus ventilation and allow access of topical medications. Wikipedia),

Микропрепаратларнинг микроскопик ва гистологик тадқиқоти Республика патологик анатомия марказининг патогистология лаборатория бўлимларида бажарилди, микропрепаратларни бўяшда гематоксилин ва эозин бўёғидан фойдаланилди. Микропрепаратларни тадқиқ қилиш ва таъриф беришда CYAN. Model DN - 30 OM. C приставкой 34 MP MICROSCOPE Camera, окуляр-объектив катталиги $\mathrm{x}=4 \mathrm{x} 10 \mathrm{x} 0,5$, $\mathrm{x}=10 \mathrm{x} 0,25 \mathrm{x} 0,5$. дан $\mathrm{x}=40 \mathrm{x} 0,65 \mathrm{x} 0,5$ гача бўлган бинокуляр микроскопдан фойдаланилди. Ушбу тадқиқот учун 23 та микрофотография тайёрланди ва таъриф берилди.

Клиникадан олиб келинган материал қуйидаги шаклда босқичма босқич амалга оширилди: материални рўйхатдан ўтказиш, кесиш, макро таъриф бериш, кассеталар маркировкаси, кассета бўйича материалларни ажратиш бирламчи диагностика, дастлабки диагнозни олиш. Кейин материалларга ишлов бериш, ойналарга белги қўйиш, препаратларни қабул қилиш ва натижаларни бахолаш ишлари олиб борилади. Хар бир тайёр микропрепаратдан илмий-тадқиқот ишларида фойдаланиш учун суратга олинди.

\section{IV. Олинган натижалар ва уларнинг мухокамаси.}

Капилляр типдаги ингичка ва юпқа деворли ангиоматоз полип беморларнинг умумий сонидан, бу тури 5 холат $-4,2$ фоизни ташкил этди.

Яллиғланишли полип 10 та холатни - 8,4 фоизни ташкил қилди, гистологик ўзгаришлар хам бириктируви тўқимада оралиқ шиш билан бирга лимфоцит ва гистиоцитдан иборат диффуз полиморф яллиғланишли-хужайрали инфильтрация билан тавсифланади, сурункали жараён авж олганда якка йирик, секретор фаол безларда қон кетиш ўчоқлари, плазматик хужайралар аралашган полиморф ядроли лейкоцитлар сони ортиши кузатилди.

Полипнинг безли - кистозли шакли - 8 холатда аниқланди, бу эса 6,7 фоизни ташкил этиб, юзаси пролиферация ўчоқлари, десквамация ва метаплазия сохалари бўлган кўп қаватли ясси мугузланмайдиган эпителийда кўп қаторли цилиндрсимон хилпилловчи эпителий билан қопланган. Стромаси нотекис шиш, тарқоқ лимфогистиоцитар инфилтрация, ангиоматоз ва кўплаб кистоз-кенгайган сероз безлар билан ғовакли бириктирувчи тўқима кўринишида ифодаланади. Алохида безлар эпителиал 
хужайраларнинг пролиферация холатида бўлиб, улар кўп қаторли ва кўп қаватли жойлашган.

Безли-шиллиқли полип 12 холатни - 10,3 фоизни ташкил этиб, юзаси пролиферация ўчоқлари бор бўлган кўп қаторли цилиндрсимон эпителий билан қопланган. Стромаси миксоид шишли, ангиоматоз ва плазма хужайралари аралашган кўплаб эозинофил лейкоцитлардан иборат шиллиқланувчи бириктирувчи тўқимадан иборат. Полип тўқимасининг ичида сероз суюқлик тутган, ички девор эпителий қопламининг атрофияси ва яссиланиши бўлган, кистоз-кенгайган бўшлиқли безлар аниқланади.

Фиброзли полип 12 та холатда - 10,3 фоиз аниқланиб, базал мембранаси тўлиқ тушиб қолиши, тўлиқ эпителий десквамацияси сохалари бор бўлган кўп қаватли цилиндрик эпителий билан қопланган шиллиқ қавати овалсимон бўккан кўринишида. Стромаси камгина шиллиқ безлар ва томирлар тўпланиши билан қалин лимфогистиоцитар инфилтрацияли, зич баъзан дағал толали фиброз тўқималардан иборат.

3 та, яъни 2,5 фоиз холатда эпителийнинг ясси хужайрали метаплазияси билан пролиферацияланувчи полиплар аниқланди. Метаплазия бурун шиллиқ қавати ва бурун олд бўшлиқлари эпителийсида диспластик ва пренеопластик ўзгаришлар ривожланиши билан хавфлидир.

1 жадвал

COVID-19 билан касалланган беморлар юзида йирингли-некротик жарохатларнинг клиник-морфологик шакллари

\begin{tabular}{|c|c|c|c|}
\hline $\mathbf{N}$ & $\begin{array}{r}\text { Йирингли-некротик } \\
\text { жарохатларнинг турлари }\end{array}$ & $\begin{array}{l}\text { Холатлар } \\
\text { сони }\end{array}$ & $\begin{array}{l}\text { Фоизга } \\
\text { нисбатан }\end{array}$ \\
\hline 1 & Мукормикоздан шикастланиш & 39 & $33 \%$ \\
\hline 2 & Candida Albicans & 8 & $6,7 \%$ \\
\hline 3 & Сур.яллиғ.фонида мукормикоз & 12 & $10,3 \%$ \\
\hline 4 & $\begin{array}{l}\quad \text { Диморфли } \\
\text { (мукормикоз+кандидоз) } \\
\text { шикастланиш. }\end{array}$ & 9 & $7,6 \%$ \\
\hline 5 & Ангиоматоз полип & 5 & $4,2 \%$ \\
\hline 6 & Яллиғланишли полип & 10 & $8,4 \%$ \\
\hline 7 & Безли - кистозли полип & 8 & $6,7 \%$ \\
\hline 8 & Безли-шиллиқли полип & 12 & $10,3 \%$ \\
\hline 9 & Фиброзли полип & 12 & $10,3 \%$ \\
\hline 1 & Пролиферацияланувчи & 3 & $2,5 \%$ \\
\hline
\end{tabular}




\begin{tabular}{|l|l|l|l|}
\hline 0. & эпителий метаплазияси билан & & \\
\hline & Жами & $\mathbf{1 1 8}$ & $\mathbf{1 0 0} \%$ \\
\hline
\end{tabular}

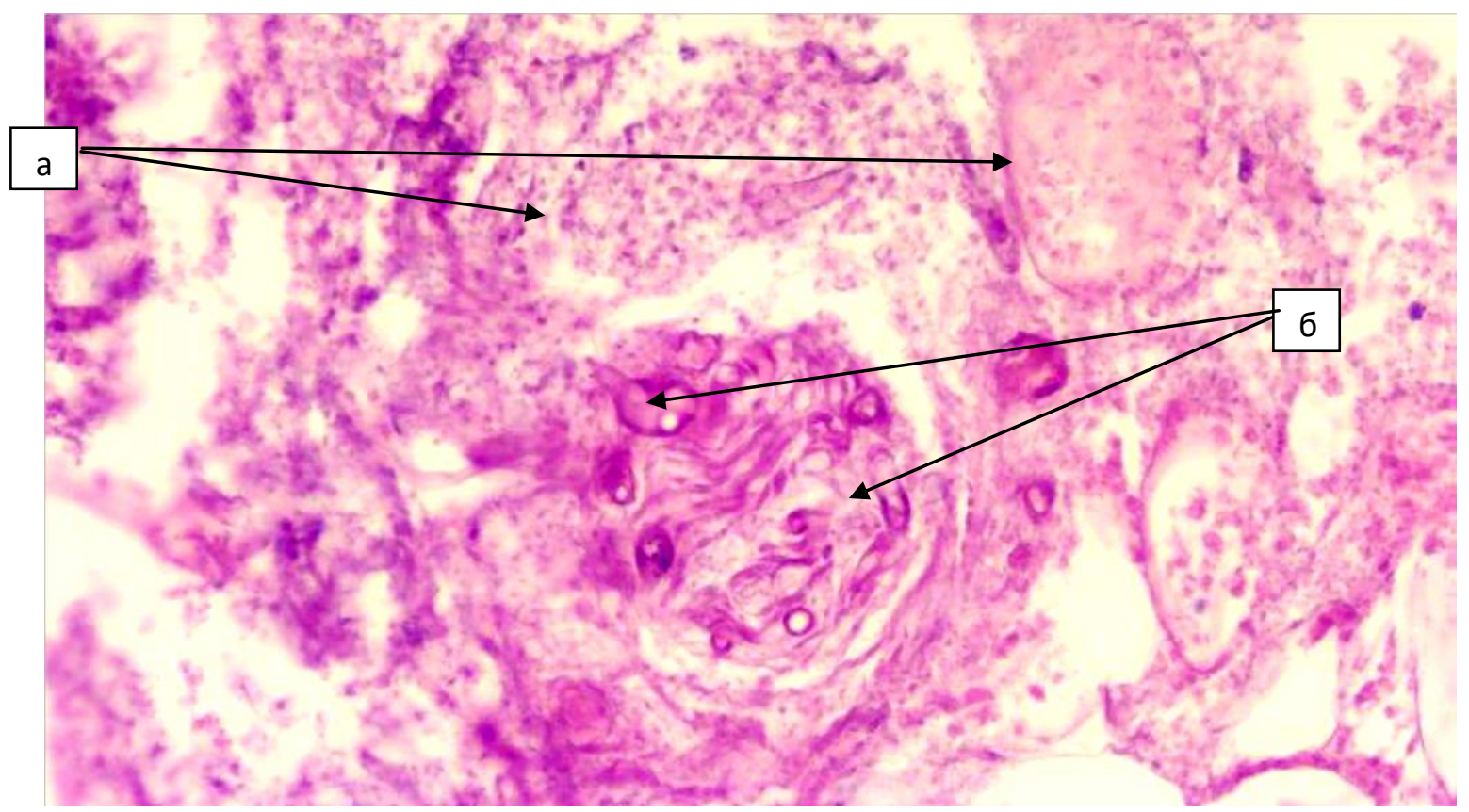

1 расм. Тўқиманинг юзаси етилган, юпқалашган ясси эпителий билан қопланган, унинг остида массив некрозланган фиброзли-ёғ тўқимаси, кўплаб лейкоцитлар тўпланиши ва камгина тери ости ортиғи мавжуд бўлиб (а), марказида кўплаб бироз қалинлашган фрагментлар аниқланиб, учлари тўғноғичсимон шаклида қалинлашган мукормикознинг шохланган мицелийлари аниқланади (б). Шишган респираторли қопламнинг остида катталашган, тўлақонли томирларнинг кўп сонли гурухлари бор. Стромаси қон куйилишлар, секретор фаол шиллиқ безлар, томирлар тромбози, ингичка деструкцияланган суяк бўлаклари сохалари билан. (1 гурух) Гематоксилин ва эозин билан бўялган. Кат. обх10.0 


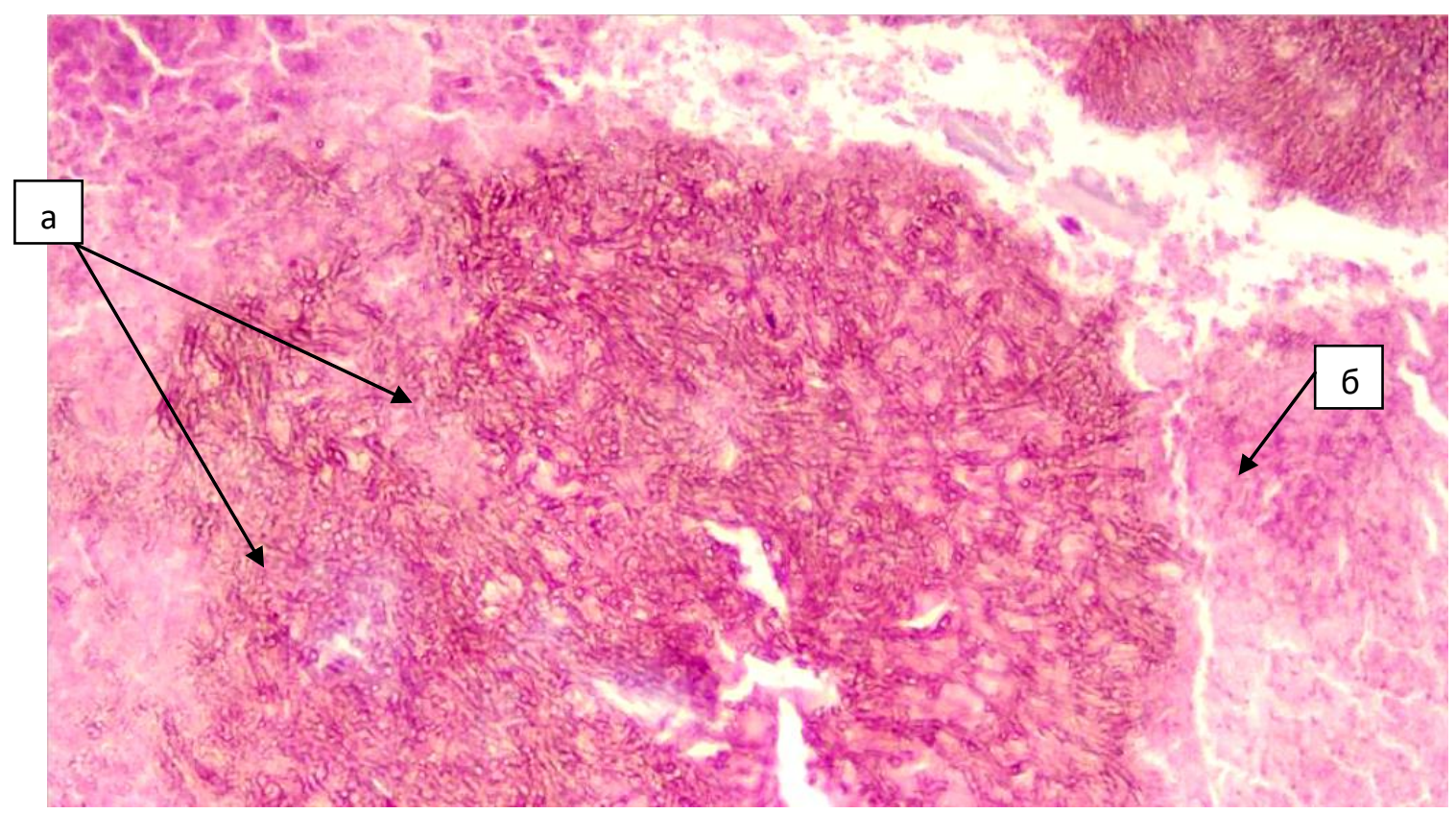

2 расм. Кенг кўп сонли некроз сохалари зич, йирик, қайтадан шохланувчи қалинлашган сегментли ёки учлари тўғноғичсимон шаклида қалинлашган мукормикознинг шохланган мицелийлари жойлашган (a), атрофида эса ўчоқли лейкоцитар инфильтрат аниқланади (б). (1 гурух) Гематоксилин ва эозин билан бўялган. Кат. об х10.

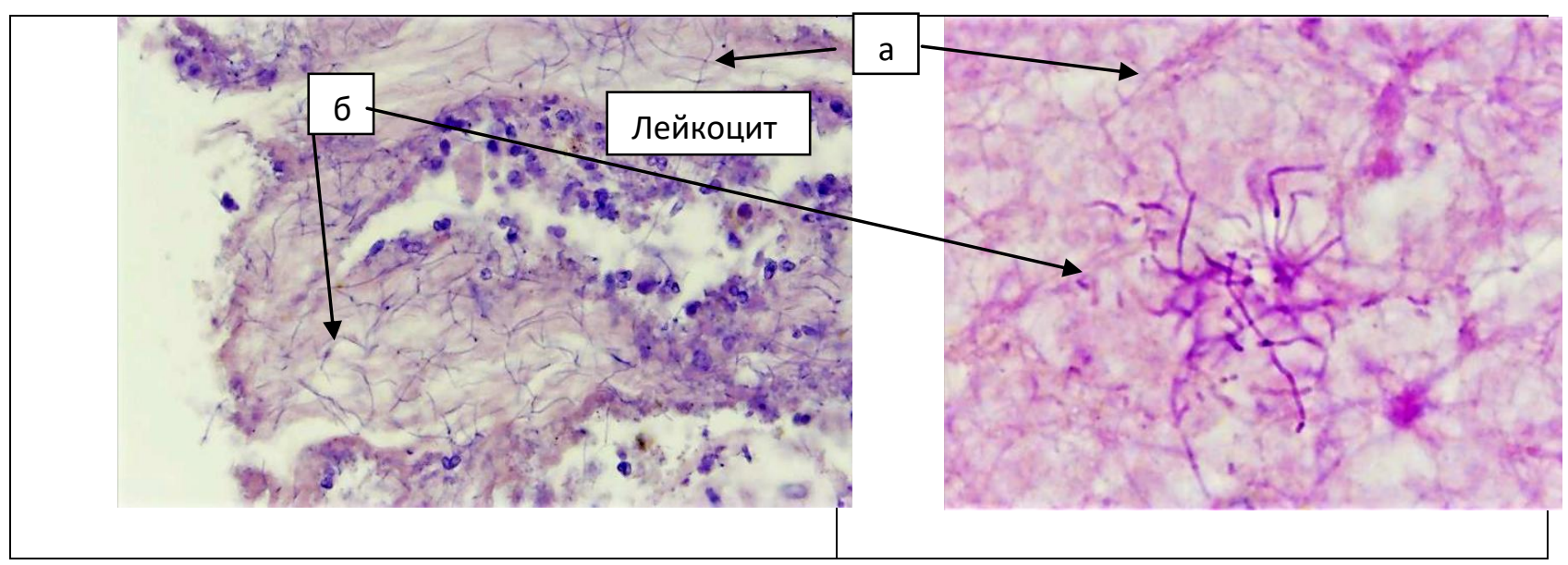

3 расм. Кесмалар, атрофида лейкоцитлар устунлиги билан зич полиморф яллиғланишли инфилтрати мавжуд бўлган катта ўчоқли некротик массалардан иборат (a). Некроз тубида шохланган, сегментланган кўп сонли гифлар, хамда алохида псевдогифлар аниқланади (б). (1 гурух) Гематоксилин ва эозин билан бўялган. Кат. об $\mathrm{x} 10.0$ 


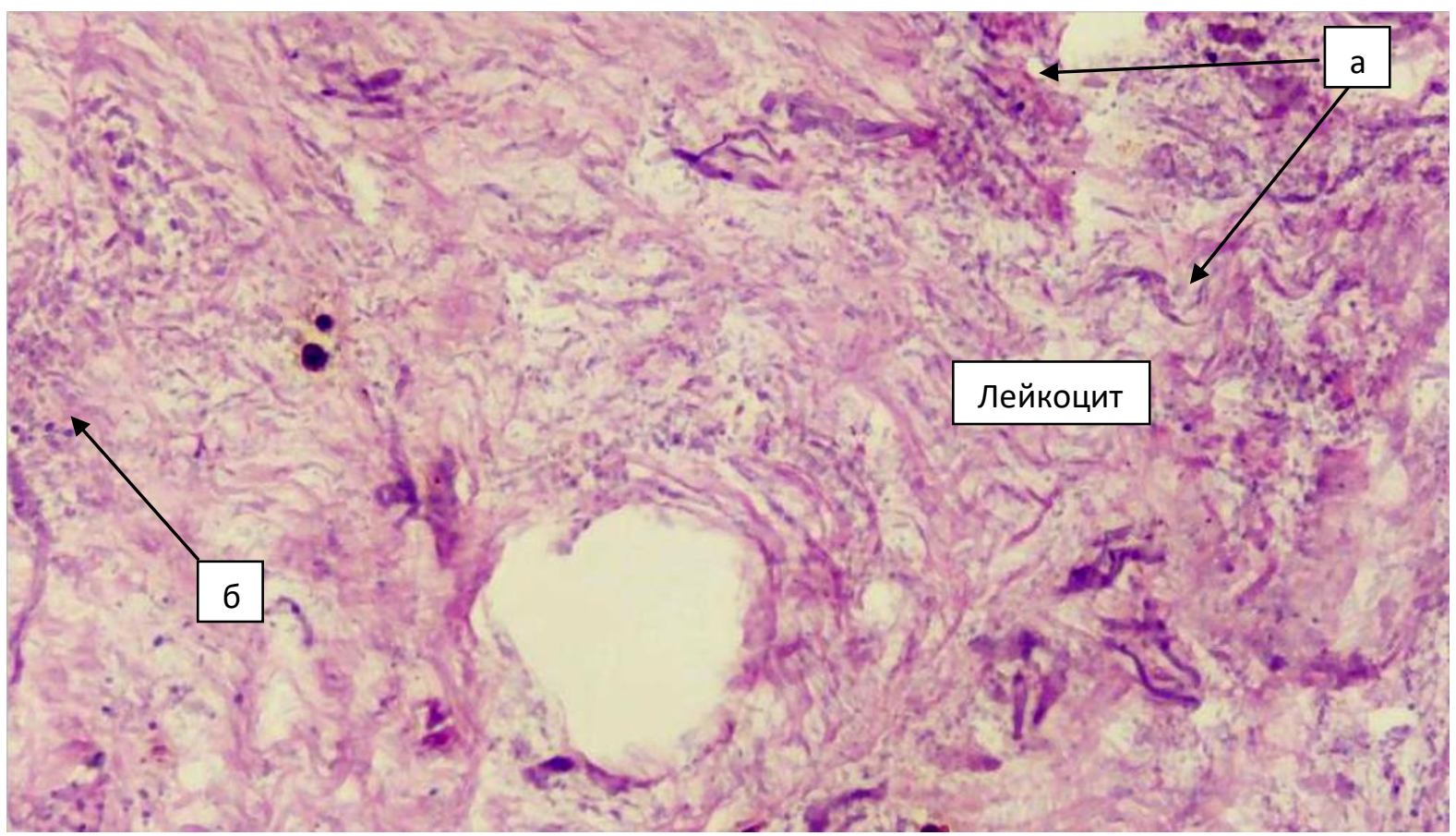

4 расм. Кесмалар, асосан некротик масса ўчоқлари, юзаки яраланган грануляцион тўқима сохаларидан иборат (а). Ўчоқли қалин лейкоцитар инфильтрат мавжуд. Қалинлашган, шохланган, мукормикознинг сегментланган мицелийлари аниқланади (б). Мукормикоз грануляцион-некротик тўқима билан. (1 гурух). Гематоксилин ва эозин билан бўялган. Кат. об х10.0

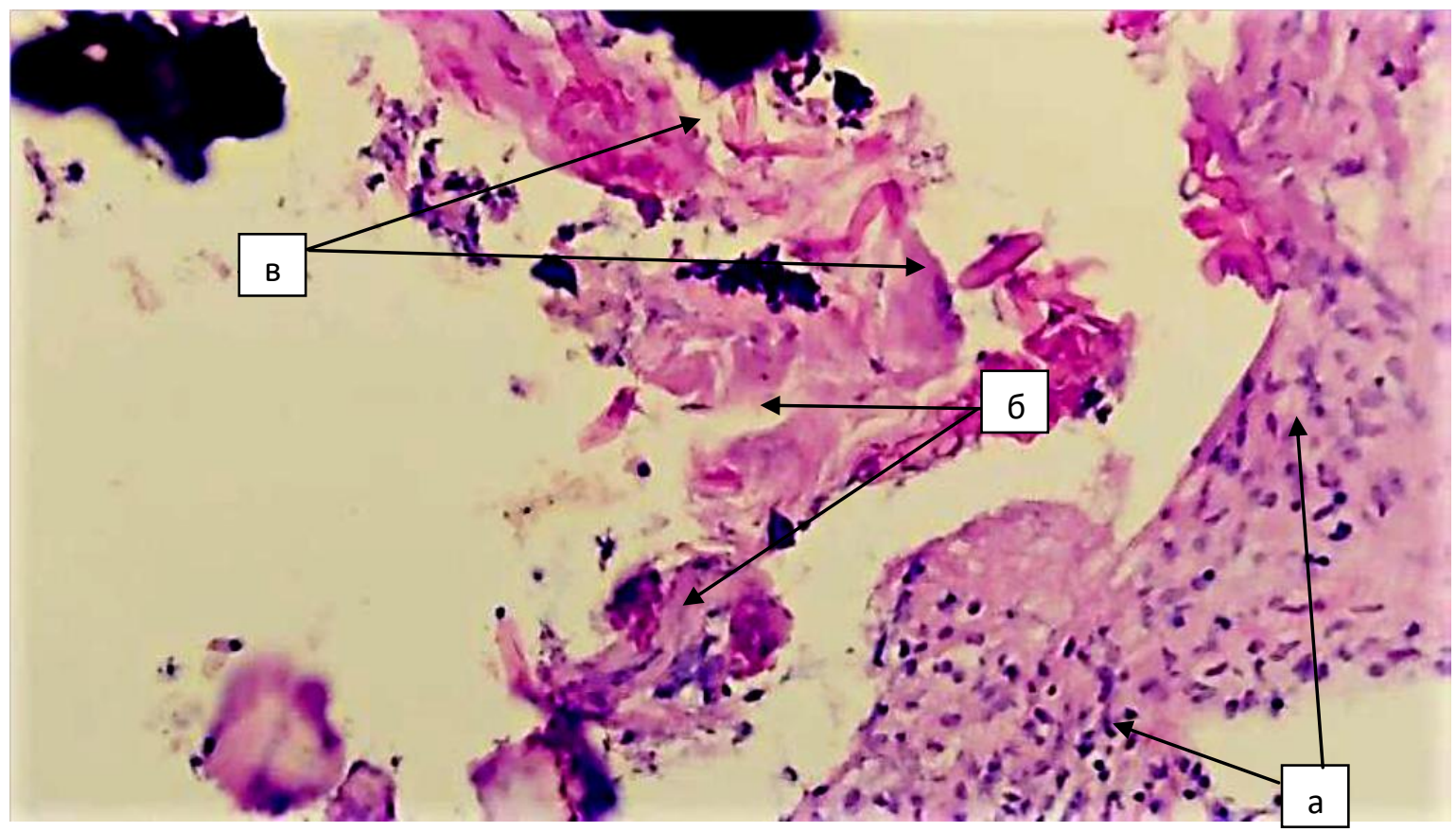

5 расм. Тўқима пролиферация ва десквамация ўчоқлари бор бўлган кўп қаторли цилиндрсимон хилпилловчи киприкли эпителий билан қопланган (а). Стромаси плазмоцит, лимфоцит ва баъзан қалин эозинофиллардан иборат яллиғланишли инфилтрат билан бирга нотекис миксоид шиш, ўчоқли шиллиқланиш бор бўлган 
бириктирувчи тўқимадан иборат (б). Қон томирлари тўлақонли. Шунингдек учлари тўғноғичсимон шаклида қалинлашган, йирик қалинган сегментланган ёки шохланган мицелийлар (в) майда некроз сохалари аниқланиб, атрофида лейкоцитар инфильтрат кўринади. Деструктив ўзгарган суяк тўқимаси ўчоқли микотик шикастланиш билан. (1 гурух) Гематоксилин ва эозин билан бўялган. Кат. об х10.0

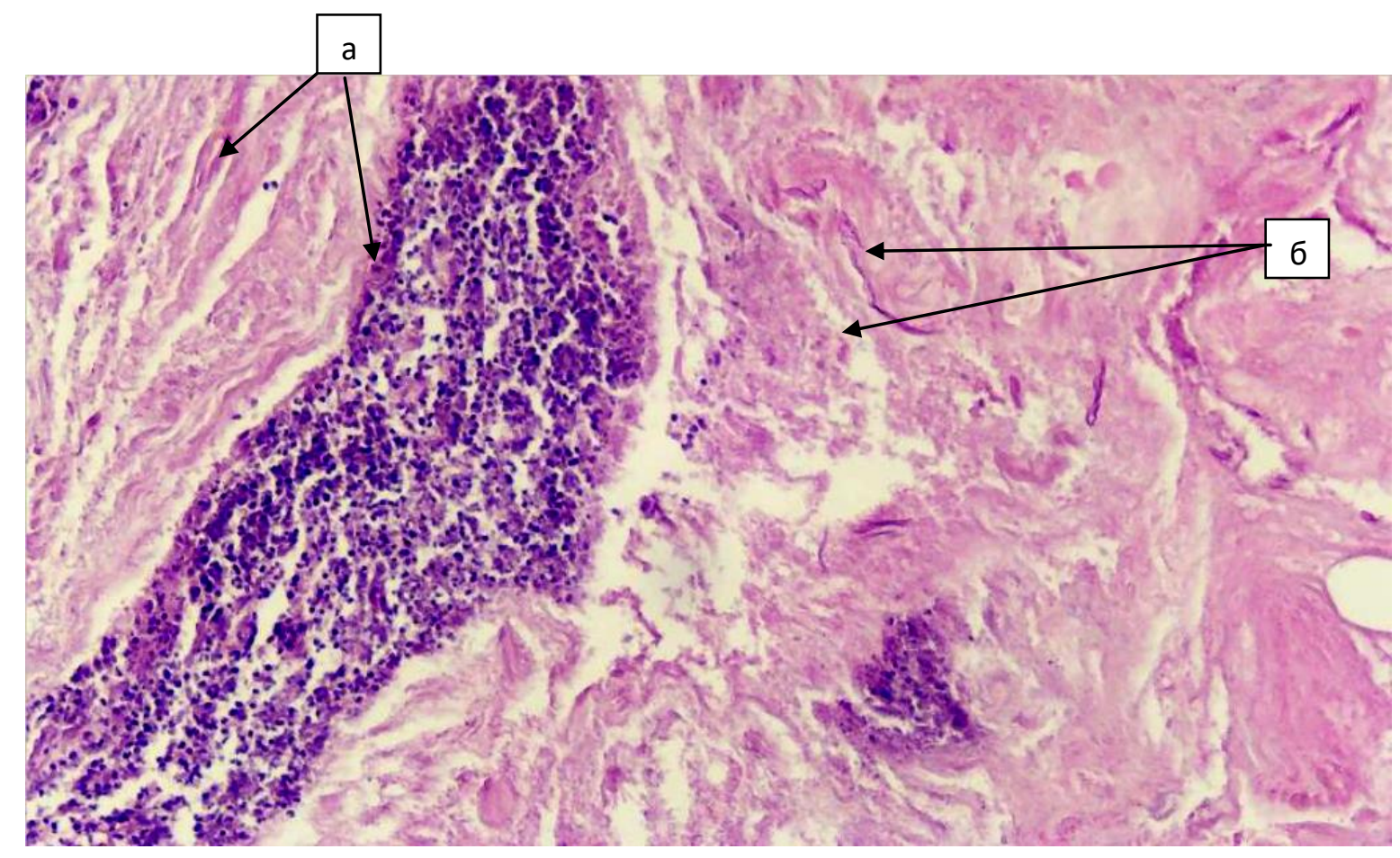

6 расм. Кесма атрофида сегмент ядроли лейкоцит тутган зич полиморф яллиғланиш инфилтрати бўлган катта ўчоқли некротик массалардан иборат (а). Некрозланган масса тубида мукормикозга хос бўлган йирик шохли, микоспорали сегментланган мицелий аниқланади (б). Мукормикотик шикастланишнинг морфологик кўриниши тўқима деструкцияси ва йирингли яллиғланиши билан. (1 гурух) Гематоксилин ва эозин билан бўялган. Кат. об х10.0 


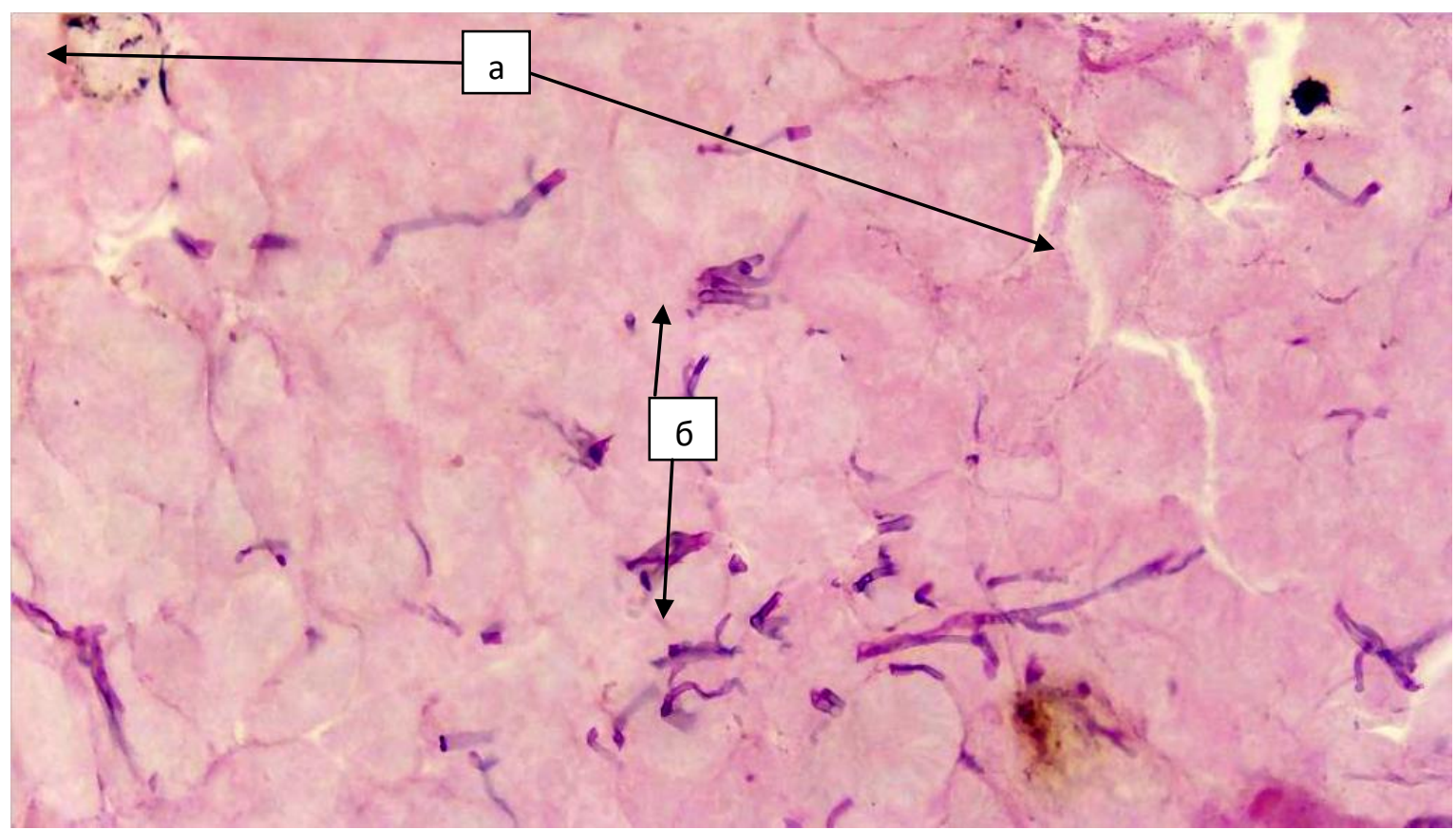

7 расм. Кесмалар асосан некротик массанинг йирик ўчоқларидан иборат бўлиб, унда лейкоцитлар, эски ва янги қон қуйилиш сохалари бўлган ўчоқли зич яллиғланиш инфилтрати мавжуд (а). Қалинлашган, нотекис, учлари тўғноғичсимон йўғонлашган, шохланган мукормикознинг сегментланган мицейлийлари учрайди (б). Массив нерозга учраган тўқимадаги мукормикоз. (1 гурух) Гематоксилин ва эозин билан бўялган. Кат. об х 10.0

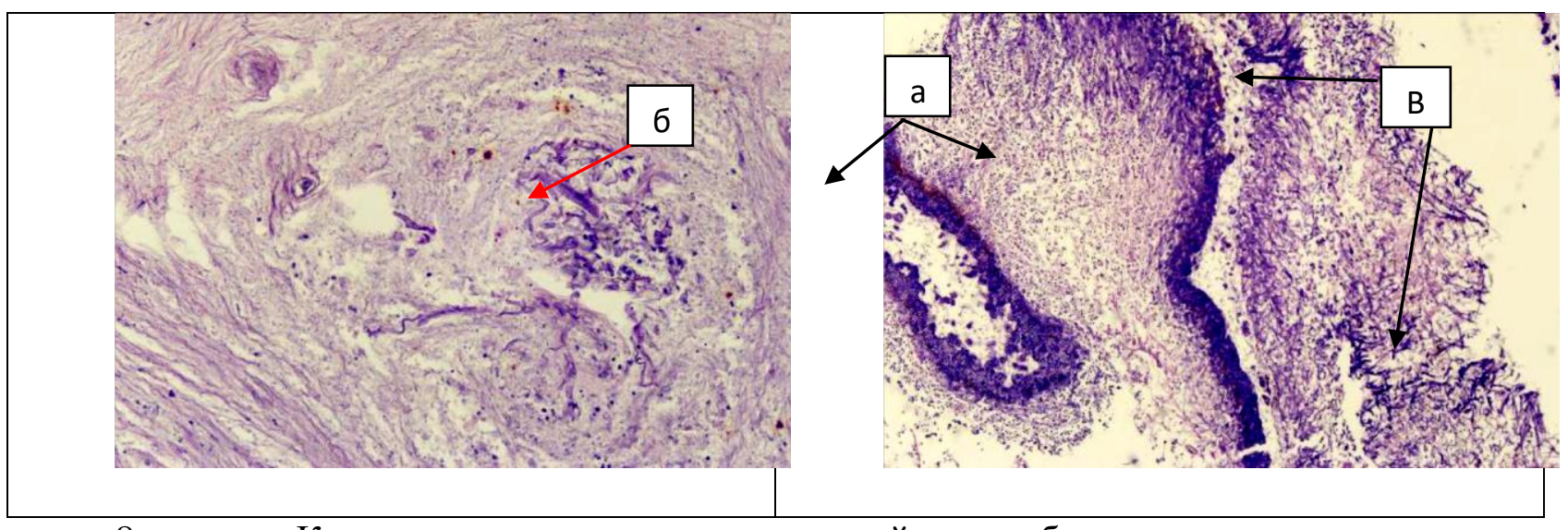

8 расм. Кесмалар асосан ксантом хужайралар билан аралашган қалин лимфогистиоцитар яллиғланиш инфилтрати, хамда лейкоцитлари кўп бўлган ўчоқли яллиғланишли инфилтрати мавжуд бўлган некроз ўчоқларидан иборат (а). Кам сонли қалинлашган, учлари тўғноғичсимон йўғонлашган мукормикоз мицелийлар тўплами аниқланади (б). Айрим кесмалар юзасида эса сегментланган кандида мицейлийсининг ингичка шохланган, зич тўплами мавжуд (в). Диморфли (мукормикоз + кандидоз) микотик шикастланиш. (1 гурух) Гематоксилин ва эозин билан бўялган. Кат. об х10.0 


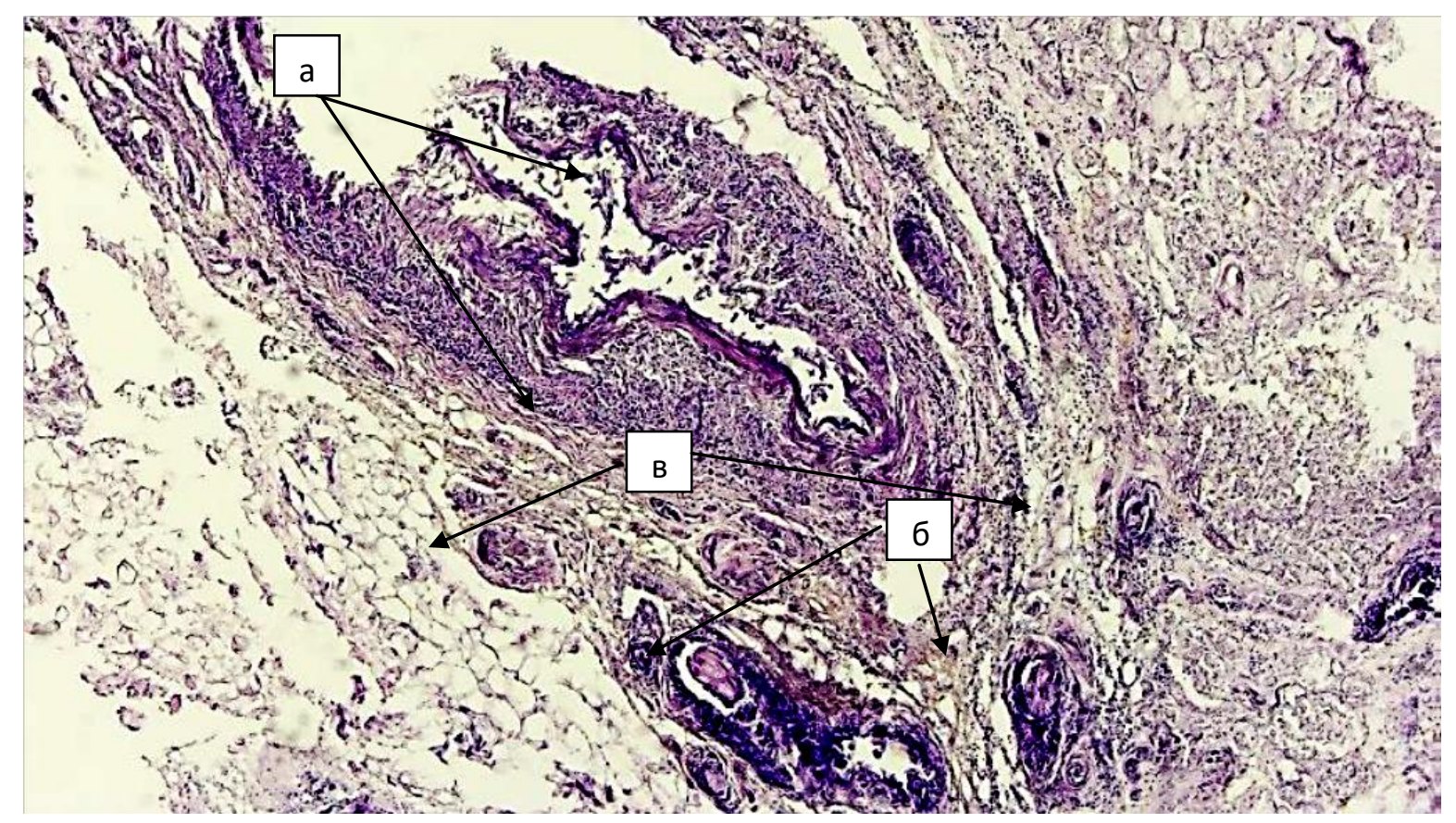

9 расм. Кесма бир қисмининг юзаси деструктив ясси хужайрали эпителий билан қопланган, унинг остидаги шишган миксоматоз тўқимада тарқалган лимфоид инфилтрация аниқланади (а). Айрим кесмалар эса некроз ўчоқларидан иборат бўлиб, орасида йирик тўлақонли ёки тромб тиқилган томирлар жойлашган (б), унга учлари шарсимон бўлган, қалин сегментланган мицелий бирикади (в). Мукормикоз шикастланиш қон томирларнинг гиперемияси ва тромбози билан. Қон томир деворининг барча қаватларига инвазияси аниқланади. (1 гурух) Гематоксилин ва эозин билан бўялган. Кат. об х 10.0

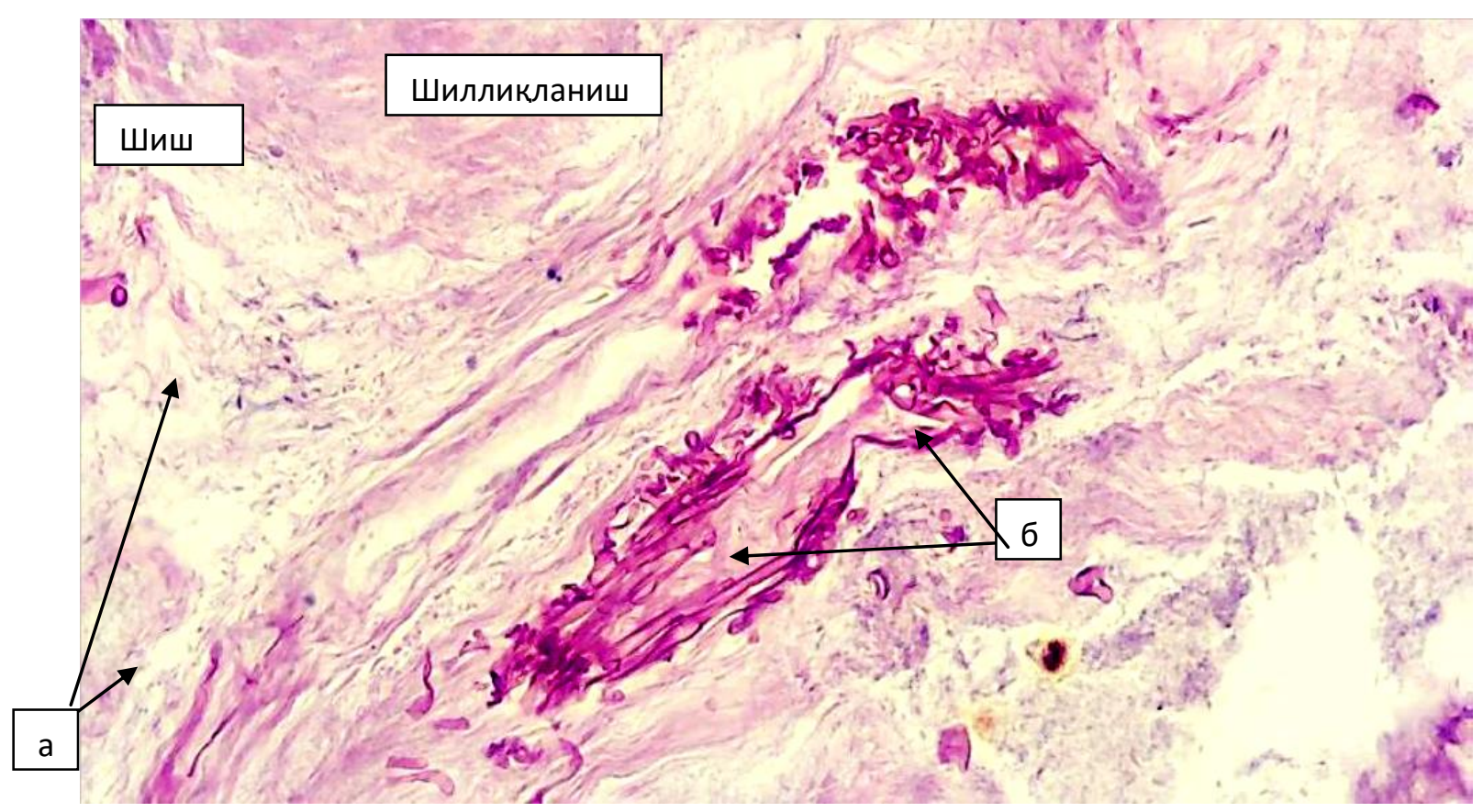


10 расм. Полипсимон хосила пролиферация ва десквамация ўчоқлари бўлган кўп қаватли ясси эпителий билан қопланган. Стромаси лимфоцитлар ва плазмоцитлардан ташкил топган нотекис миксоид шишли, ўчоқли шиллиқланиш, кўплаб лимфоцит ва плазмоцитлардан ташкил топган яллиғланишли инфилтратга бой бўлган бириктирувчи тўқимадан иборат (а). Қон томирлари тўлақонли. Яна йирик, қалинлашган сегментли ёки учлари тўғноғичсимон йириклашиб шохланган мицелийлар билан катта ўчоқли некрозлар бўлиб (б), атрофида лейкоцитар инфильтрат аниқланади. Яллиғланишли-некротик тўқима микотик шикастланиши билан бирга. Мукормикозли морфоструктура. (1 гурух) Гематоксилин ва эозин билан бўялган. Кат. об х10.0

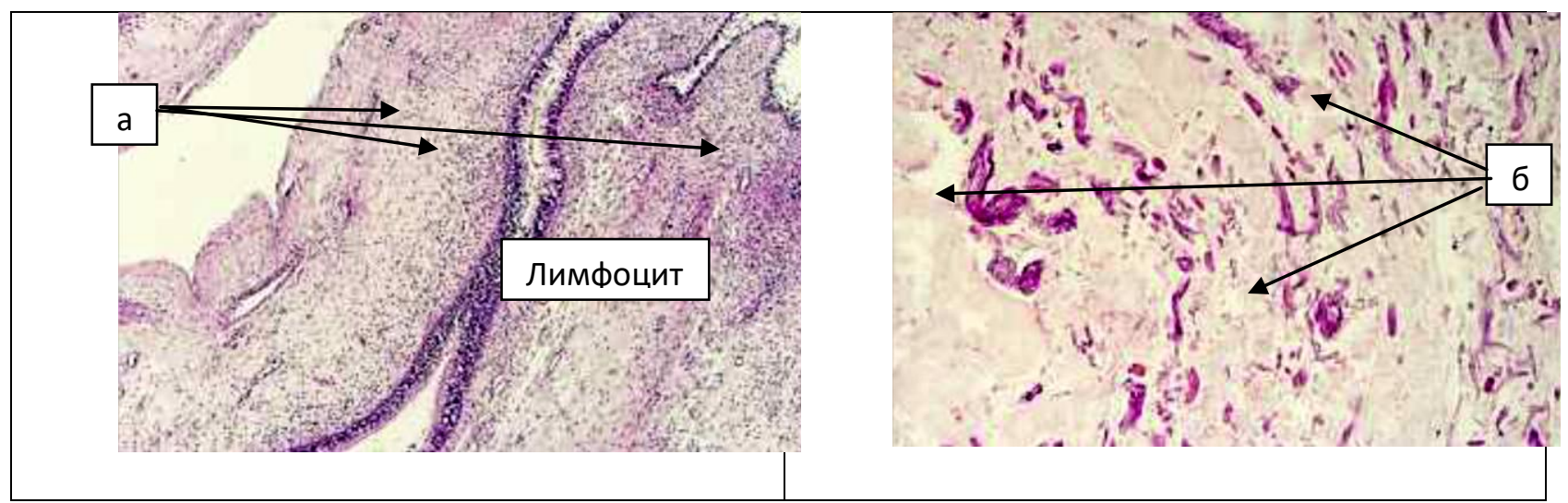

11 расм. Кесмалар асосан кистоз ўзгарган шиллиқ қават, қалин лимфоцитли, плазматик хужайрали ва гистиоцитли инфилтрациядан иборат. Тўқима юзасининг баъзи сохалари турли даражада десквамация холатидаги реактив респиратор эпителий билан қопланган (а). Кўп лейкоцитли ўчоқли қалин яллиғланишли инфилтрати мавжуд бўлган некроз сохасидан иборат. Қалинлашган, шохланган, сегментланган мукормикозни сегментланган мицелийсининг нотекис тўплами аниқланади (б). Сурункали яллиғланиш фонида ривожланган массив йирингли-некротик ўзгаришли мукормикоз морфоструктураси. (1 гурух) Гематоксилин ва эозин билан бўялган. Кат. об х10.0.

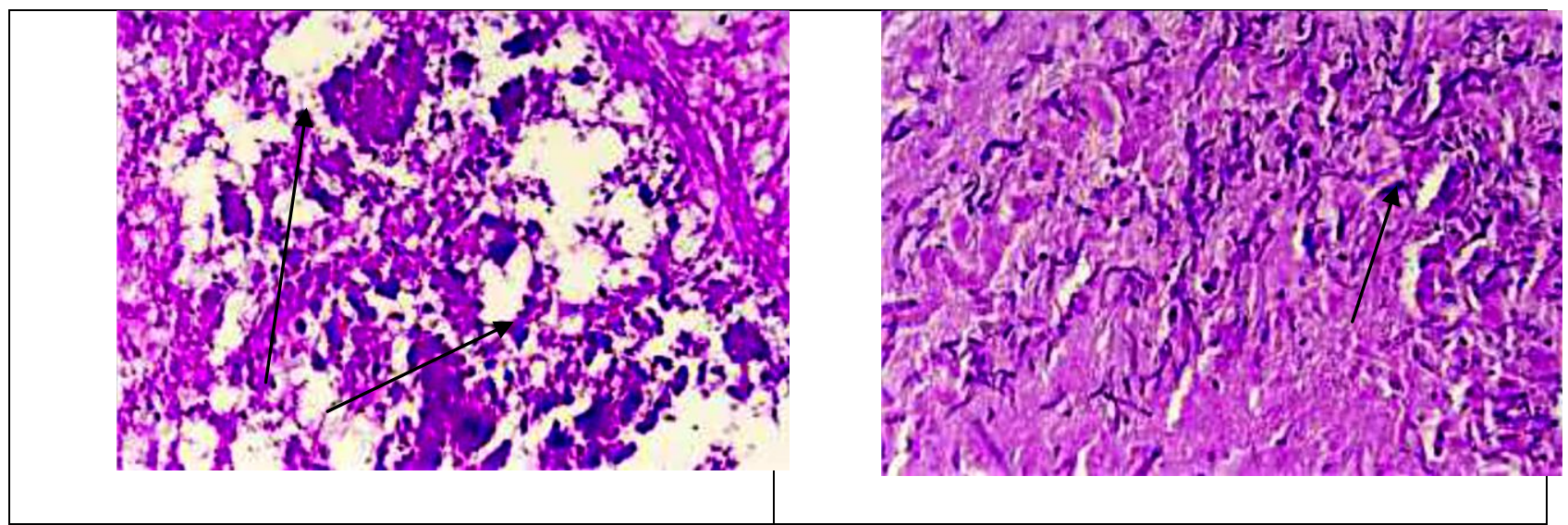

12 расм. Кесма йирик ўчоқли яраланган, қон қуйилган некроз майдонидан иборат бўлиб, ўчоқли тўпланган сегмент ядроли лейкоцитлари кўп бўлган полиморф яллиғланишли инфилтрациядан иборат (а). Мукормикоз замбуруғига хос бўлган учлари 
тўғноғичсимон кенгайиб сегментланган, қалинлашган мицелий тўпламлари аниқланди (б). Массив некрозланган мукормикозга хос замбуруғдан шикастланиш. (1 гурух) Гематоксилин ва эозин билан бўялган. Кат. об х10.0

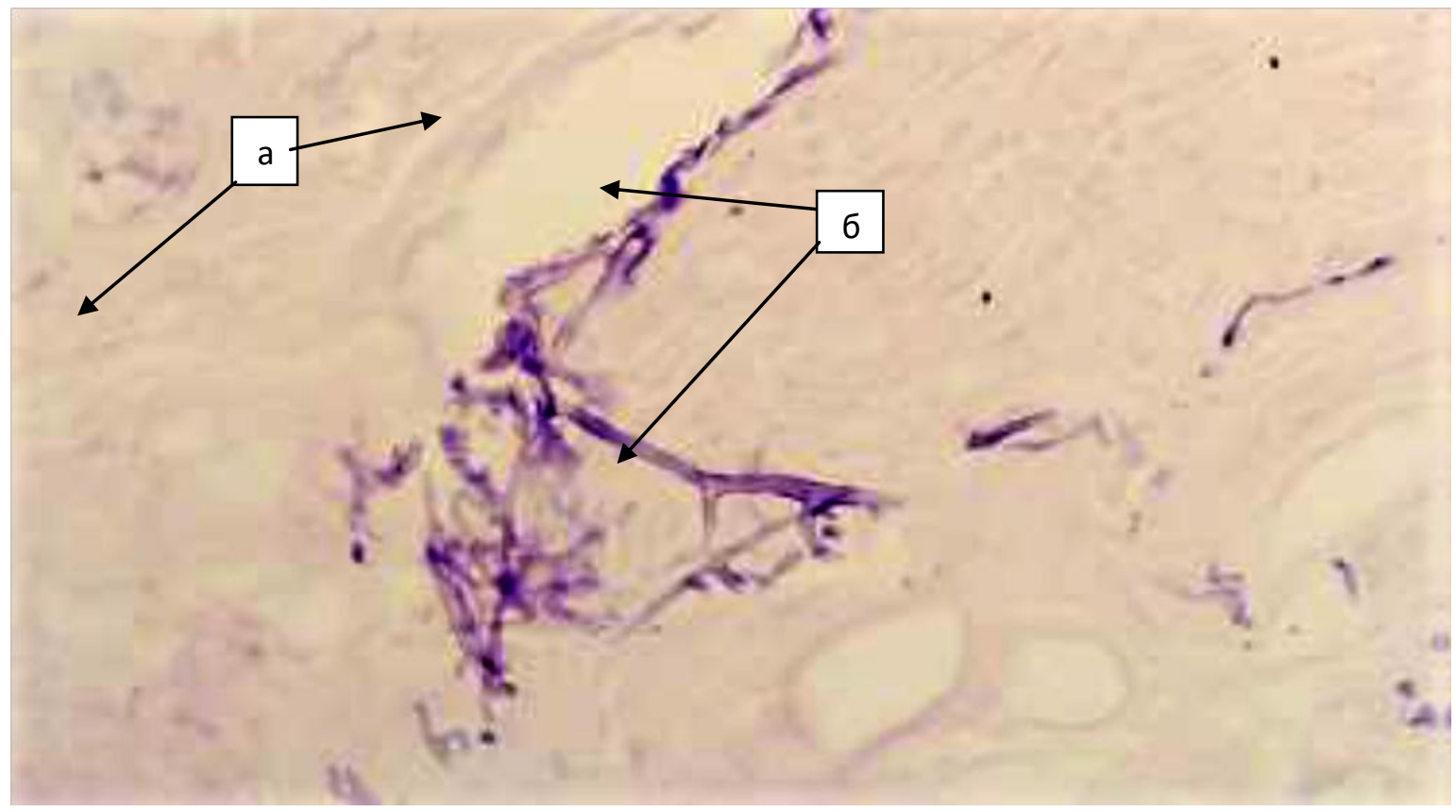

13 расм. Юзаси пролиферация ва десквамация ўчоқлари бўлган кўп қаторли цилиндрик эпителий билан қопланган полипсимон хосила. Стромаси лимфоцит ва плазмоцитдан ташкил топган қалин яллиғланишли инфильтрат, ўчоқли шилимшиқланиш, нотекис миксоид шишли бириктирувчи тўқимадан иборат (а). Қон томирлари тўлақонли. Шунингдек йирик катта сегментли ёки учлари тўғноғичсимон кенгайган шохли мицелийли кенг некроз сохалари бўлиб (б), атрофида лейкоцитар инфильтрат аниқланади. Замбуруғдан шикастланган яллиғланишли-некротик тўқима. Мукормикоз морфоструктураси. (1 гурух) Гематоксилин ва эозин билан бўялган. Кат. об х10.0

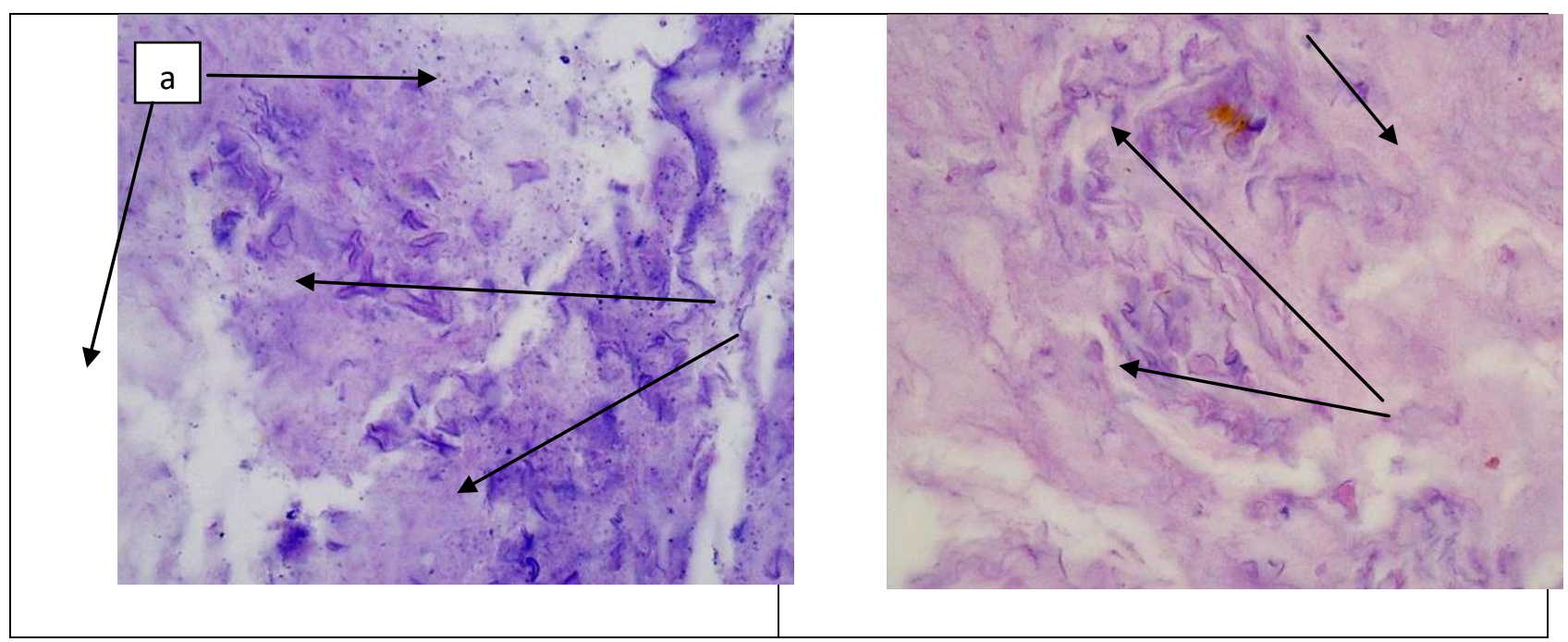


14 расм. Кесмалар катта некроз ўчоқларидан иборат бўлиб, уларнинг атрофида кўп лейкоцит тутган қалин полиморф яллиғланишли инфилтрат мавжуд (а). Некроз ичида ингичка шохланган, сегментланган мицелийлар аниқланади (б). Массив некрозли мукормикоздан шикастланиш, қалин лейкоцитар инфилтрация билан. (1 гурух) Гематоксилин ва эозин билан бўялган. Кат. об х10.0

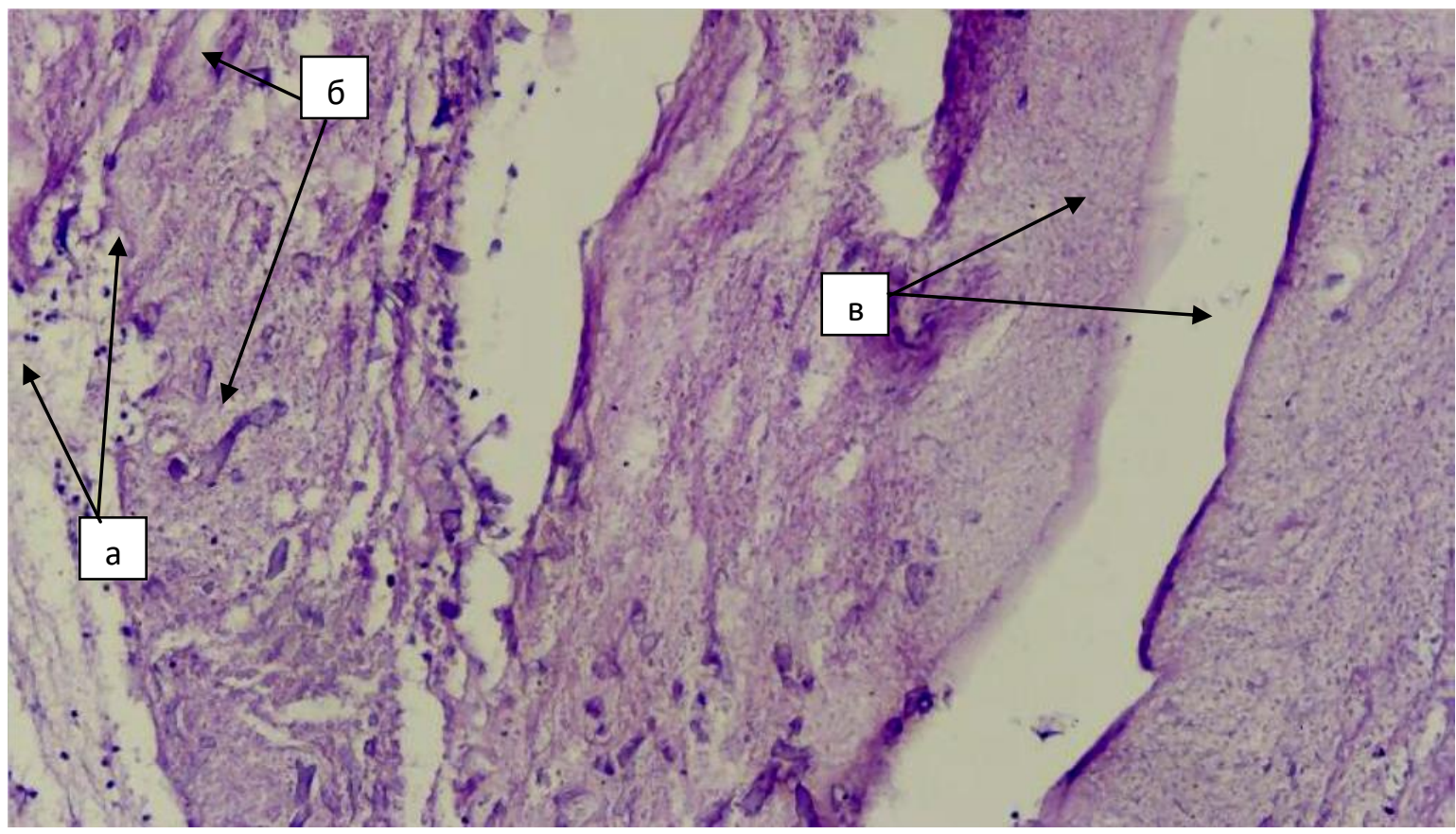

15 расм. Кесмалар асосан кўплаб сегмент ядроли лейкоцитар яллиғланишли инфилтрация ўчоқлари бўлган некротик массадан иборат (а). Учлари тўғоноқсимон кенгайган йирик сегментланган мицелийларнинг кичик ўчоқлари, жумладан томир ичида тўпланиши аниқланади (б). Тўқима юзасининг баъзи сохалари кўп қаватли ясси ёки реактив респиратор эпителий билан қопланган (в). Интраваскуляр инвазияланган мукормикоз, хамда некроз ва шу тўқиманинг йирингли яллиғланиши билан. (1 гурух) Гематоксилин ва эозин билан бўялган. Кат. об х10.0. 




16 расм. Тўқима юзасининг баъзи сохалари реактив ўзгарган кўп қаторли респиратор қоплама билан қопланган (а). юмшоқ-тўқимали компонентнинг асосий қисми некроз, лейкоцитар инфилтрация, қалинлашган, деформацияланган, шохланган, учлари йириклашган сегментланган мицелийлар тўпламидан иборат (б). Яллиғланишли-некротик ўзгаришлар фонидаги мукормикоздан шикастланиш. (1 гурух) Гематоксилин ва эозин билан бўялган. Кат. об х10.0.

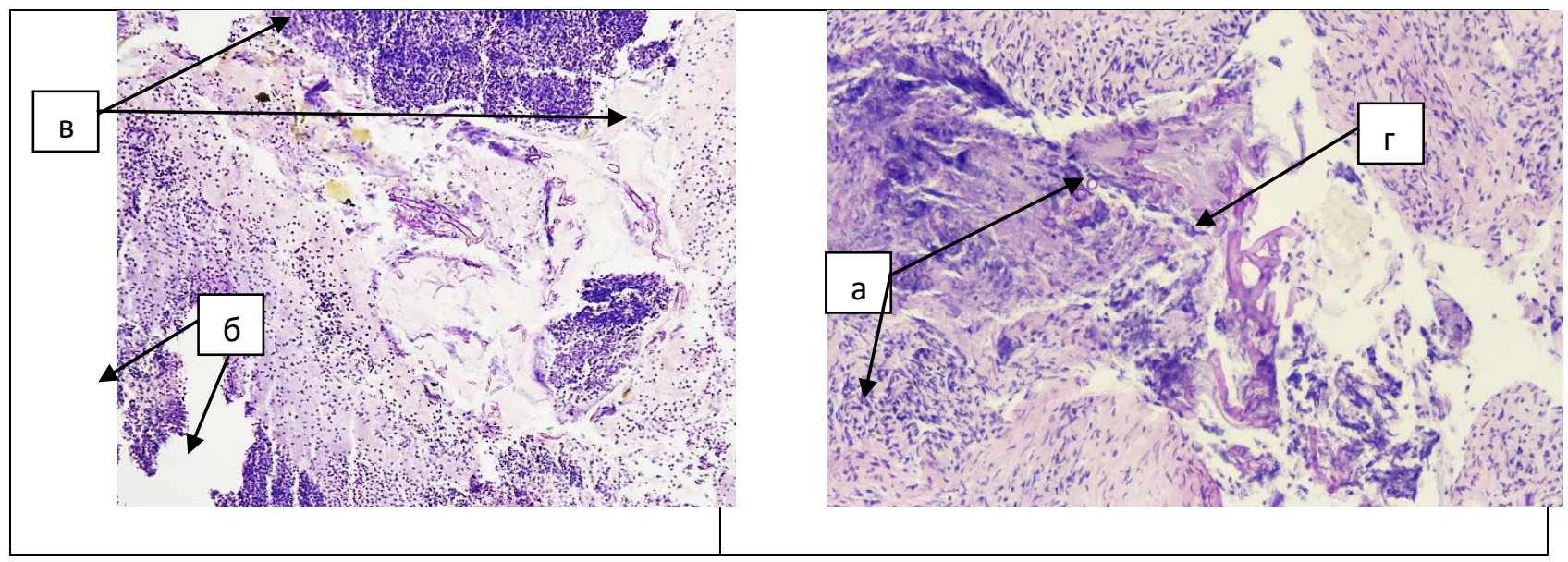

17 расм. Кесмалар кўпроқ лимфоцит, плазматик хужайра ва гистиоцитли инфилтратга бой зичлашган фиброз тўқималардан иборат (а). Тўқима юзасининг баъзи сохалари турли даражада десквамация холатидаги реактив респиратор эпителий билан қопланган (б). Лейкоцитга бой ўчоқли қалин яллиғланиш инфилтрати бўлган некротик масса сохалари мавжуд (в). Қалинлашган, шохланган, мукормикознинг сегментланган мицелийларининг нотекис тўплами аниқланади (г). Мукормикоз с массивными гнойнонекротическими изменениями на фоне хронического воспаления 
Сурункали яллиғланиш фонидаги мукормикоз, массив йирингли-некротик ўзгаришлар билан. (1 гурух) Гематоксилин ва эозин билан бўялган. Кат. об х10.0.

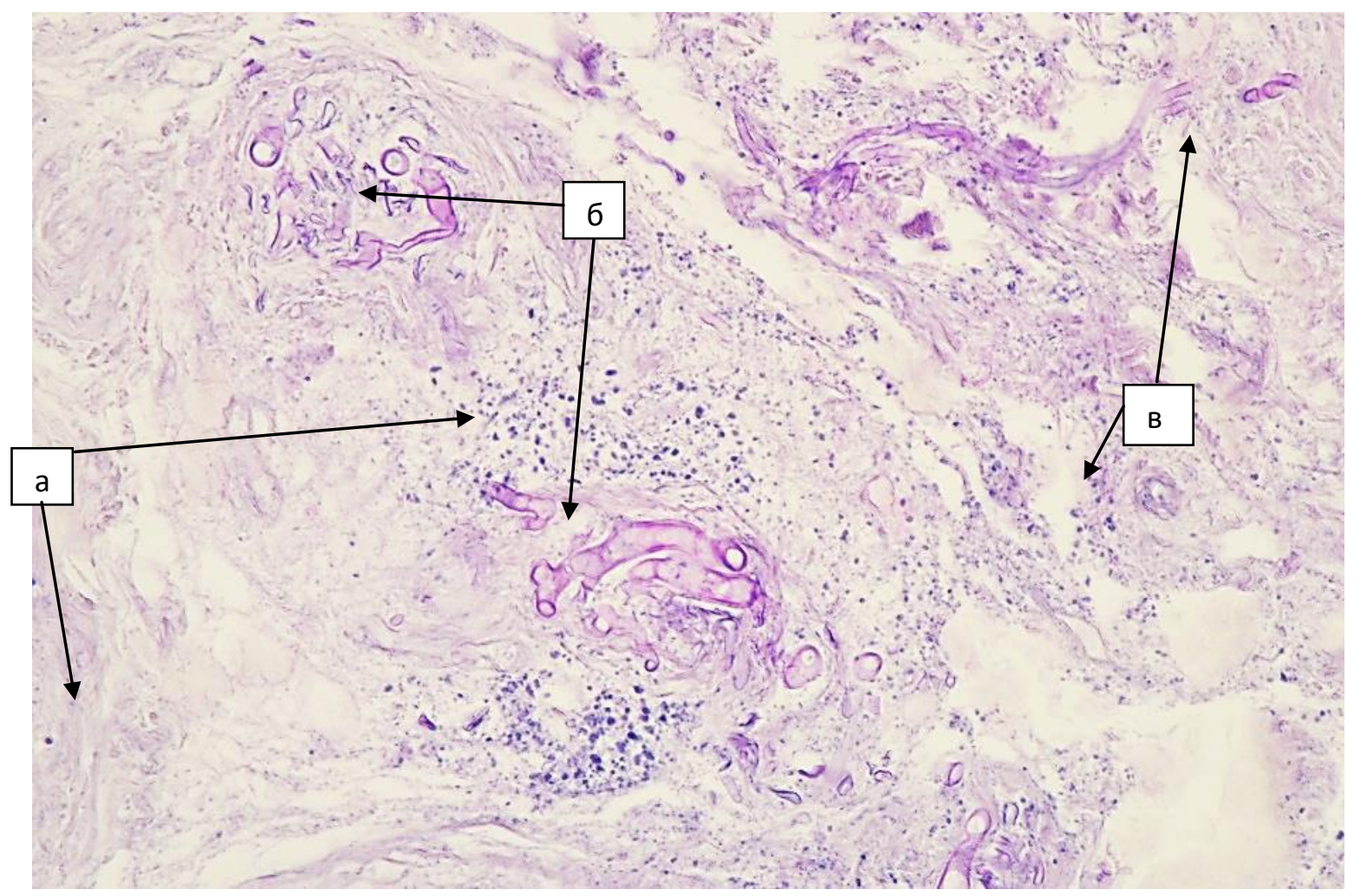

18 расм. Кесма катта ўчоқли некротик массалардан, сегмент ядроли лейкоцитларни кўп тутган қалин полиморф яллиғланишли инфилтратдан иборат (а). Некротик масса орасида якка қалинлашган, шохланган, учлари кенгайган сегментланган мицелийлар аниқланади (б). Қон томир бўшлиқлари кам қонли, улар атрофида бириктирувчи тўқималарнинг концентрик фрагментлари учрайди (в). Массив некроз, йирингли яллиғланиш билан мукормикоздан шикастланиш. (2 гурух) Гематоксилин ва эозин билан бўялган. Кат. об х10.0

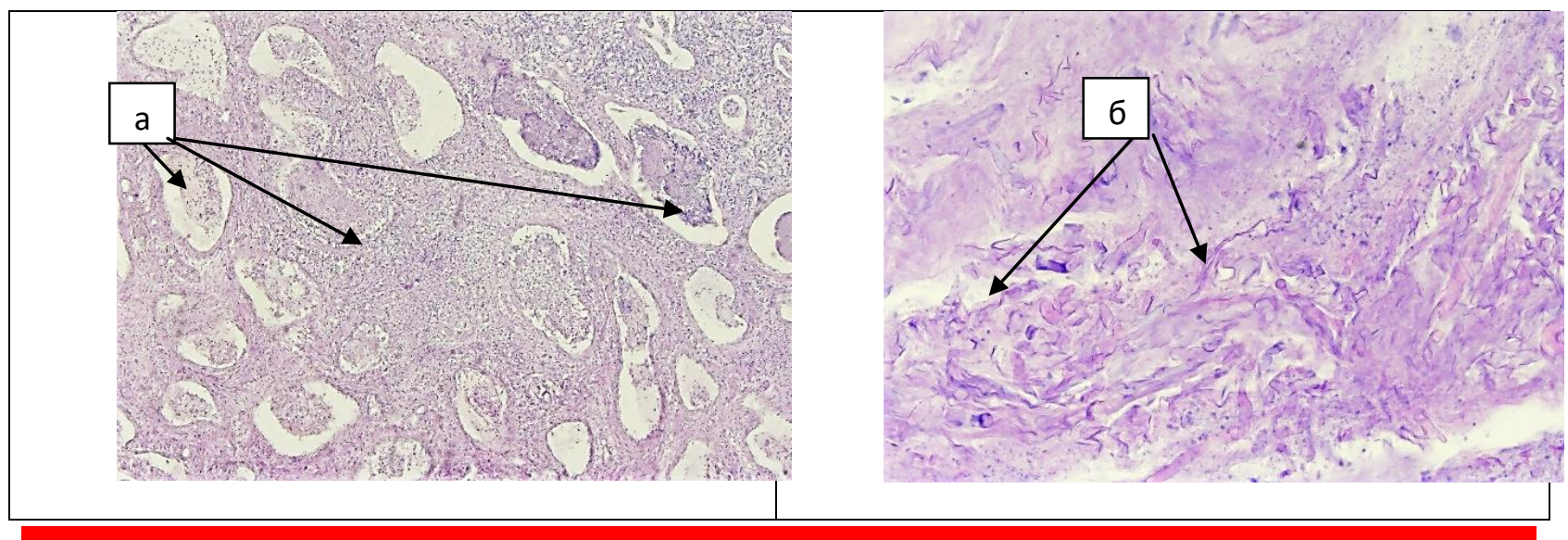


19 расм. Тўқима юзаси пролиферация ва десквамация ўчоқлари бор бўлган кўп қаторли цилиндрик хилпилловчи киприксимон эпителий билан қопланган. Унинг остида қон билан имбибицияланган, катта уччқли яллиғланишли инфилтрат аниқланади, унинг атрофида эса гиалиноз майдонлари аниқланиб, орқасида деворлари қалинлашган, тўлақонли, бўшлиқларида тромбози бўлган алохида катта томир деворининг фибриноид некрози жойлашган (а). Шунингдек учлари тўғноғичсимон қалинлашган, сегментланган ёки шохланган мицелий сохалари аниқланади (б). (2 гурух) Гематоксилин ва эозин билан бўялган. Кат. об.х 10.0

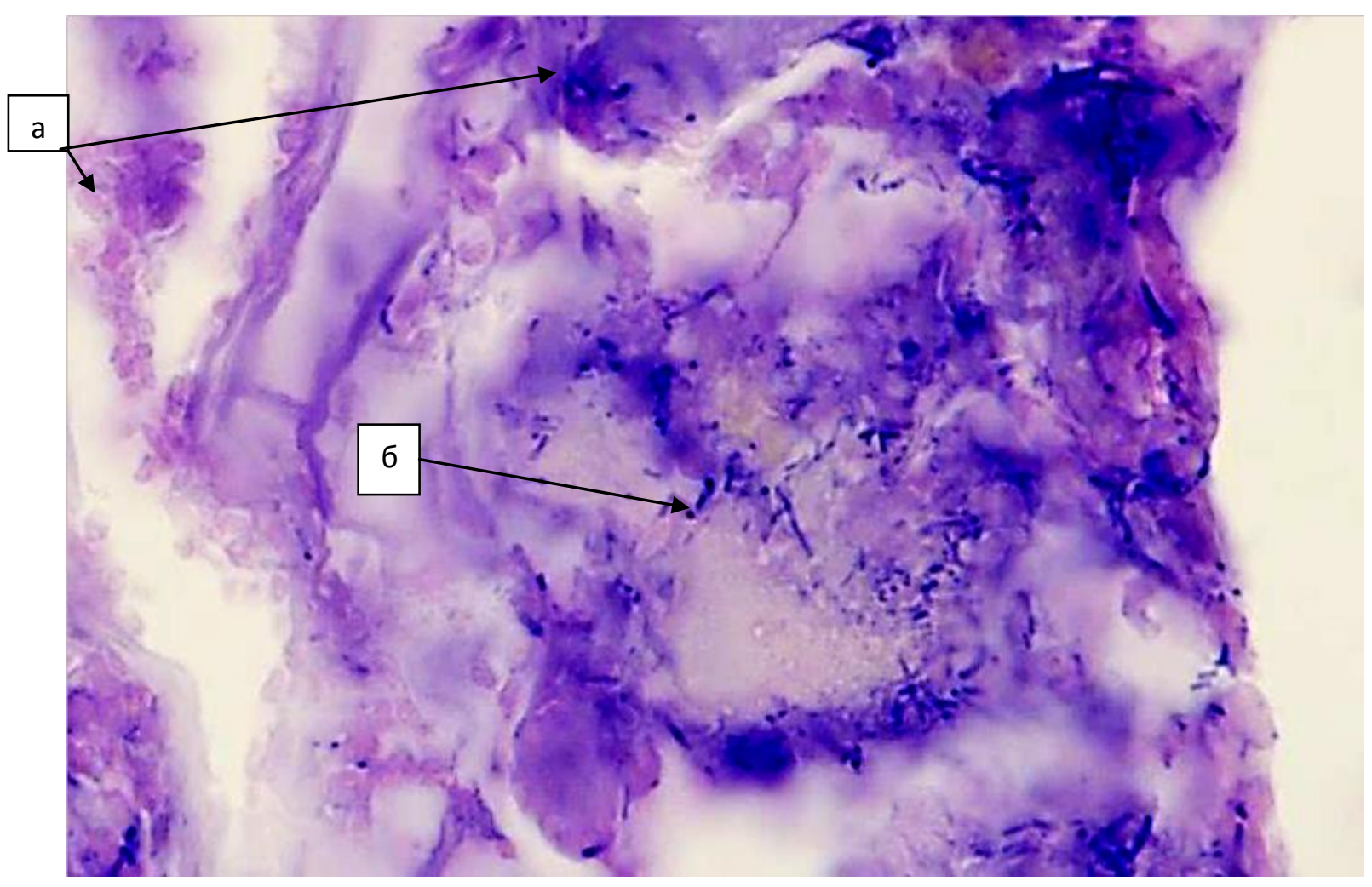

20 расм. Жадал некроз фонида лимфоцитар ва нейтрофил инфилтрациянинг кўплаб элементлари учрайди (а). Хамда ингичка мицеляр толалар кўринишида таёқчали аспергилл замбуруғ микроорганизмлари аниқланади (б). (2 гурух) Гематоксилин ва эозин билан бўялган. Кат. об.х 10.0

Кузатувларнинг иккинчи гурухидаги 50 та беморнинг нафас йўли шиллиқ қаватида хилпилловчи киприксимон эпителий хужайра пролиферацияси билан майда безли найчалар бўлиб, эпителийсининг атрофияси билан бўшлиғида секрети бор кистоз ўзгарган бўшлиқли безлар аниқланади. Қопловчи эпителий кистоз ўзгарган ва призматик ёки цилиндрик эпителий кўринишида ифодаланади. Стромасининг кўп қисми без бўшлиғининг кенгайиши хисобига кўчган, баъзи жойларида нотекис яллиғланиш-хужайрали инфилтрация ва миксоматоз ўзгаришлар кузатилади. 


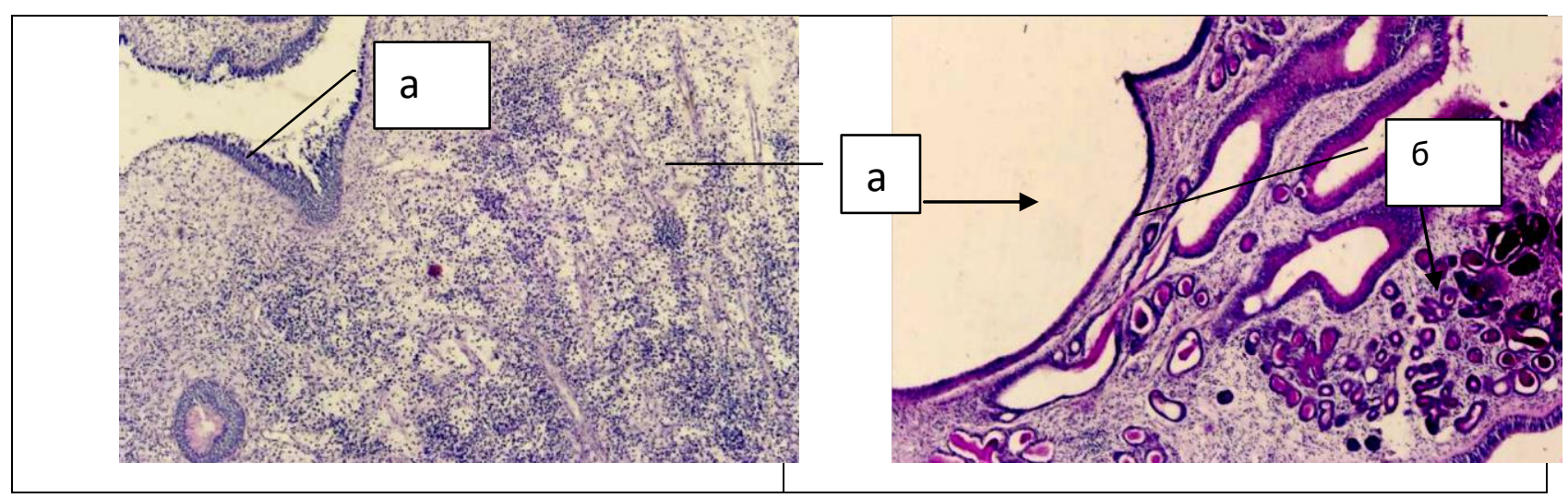

21 расм. Бурун шиллиқ қаватининг кўплаб фрагментлари полипоз тузилишга эга бўлиб, пролиферация ва қисман десквамация сохаларига эга респиратор эпителий билан қопланган (а). Стромаси яхши ривожланган, фиброз, миксоид шиш, қалин яллиғланиш инфилтрация, секрецияси фаол шиллиқ безларнинг кўплаб ўчоқлари бўлган йирик кистоз кўринишидаги баъзи безлар мавжуд (б). Кистоз сохалари бор бўлган яллиғланишли-безли полип. Замбуруғдан шикастланиш аниқланмади. (1 гурух) Гематоксилин ва эозин билан бўялган. Кат. Об х10,0.

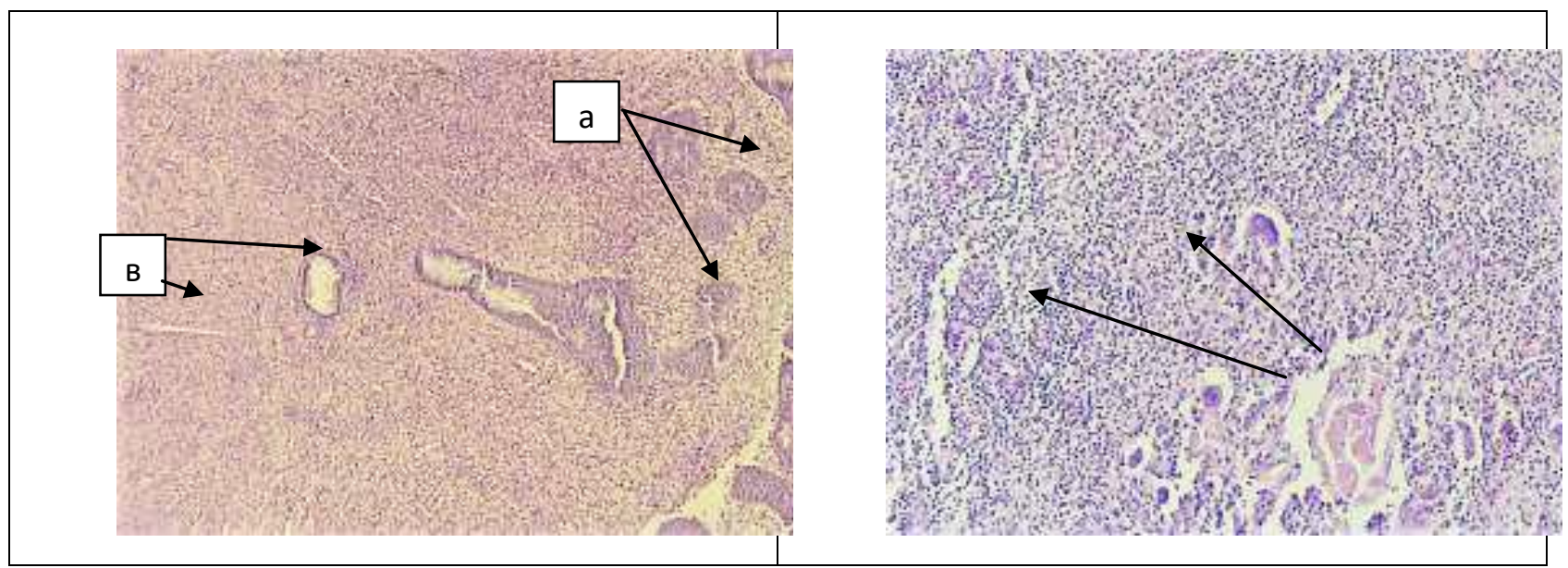

22 расм. Полипсимон хосила фрагментлари, юзаси десквамация ва пролиферация ўчоқлари бўлган кўп қаторли цилиндрик киприксимон эпителий билан қопланган бўлиб (a), остида ёт танача туридаги лимфолейкоцитлар, эозинофиллар ва кўп ядроли хужайралар кўринишидаги қалин полиморф хужайрали яллиғланиш инфилтрацияси мавжуд (б). Шунингдек, хам катта-ретенцион кенгайган, хам ўрта ва майда ўлчамли овал шаклдаги серозли-шиллиқ безлар тўплами мавжуд (в). Кучли ривожланган фиброзли строма, жадаллашган шиш, ангиоматоз, қон томир гиперемияси ва қон қуйилиш ўчоқлари билан. Грануляцион тўқима гигант хужайрали реакция ва эозинофилия билан. (2 гурух) Гематоксилин ва эозин билан бўялган. Кат. об х10.0 


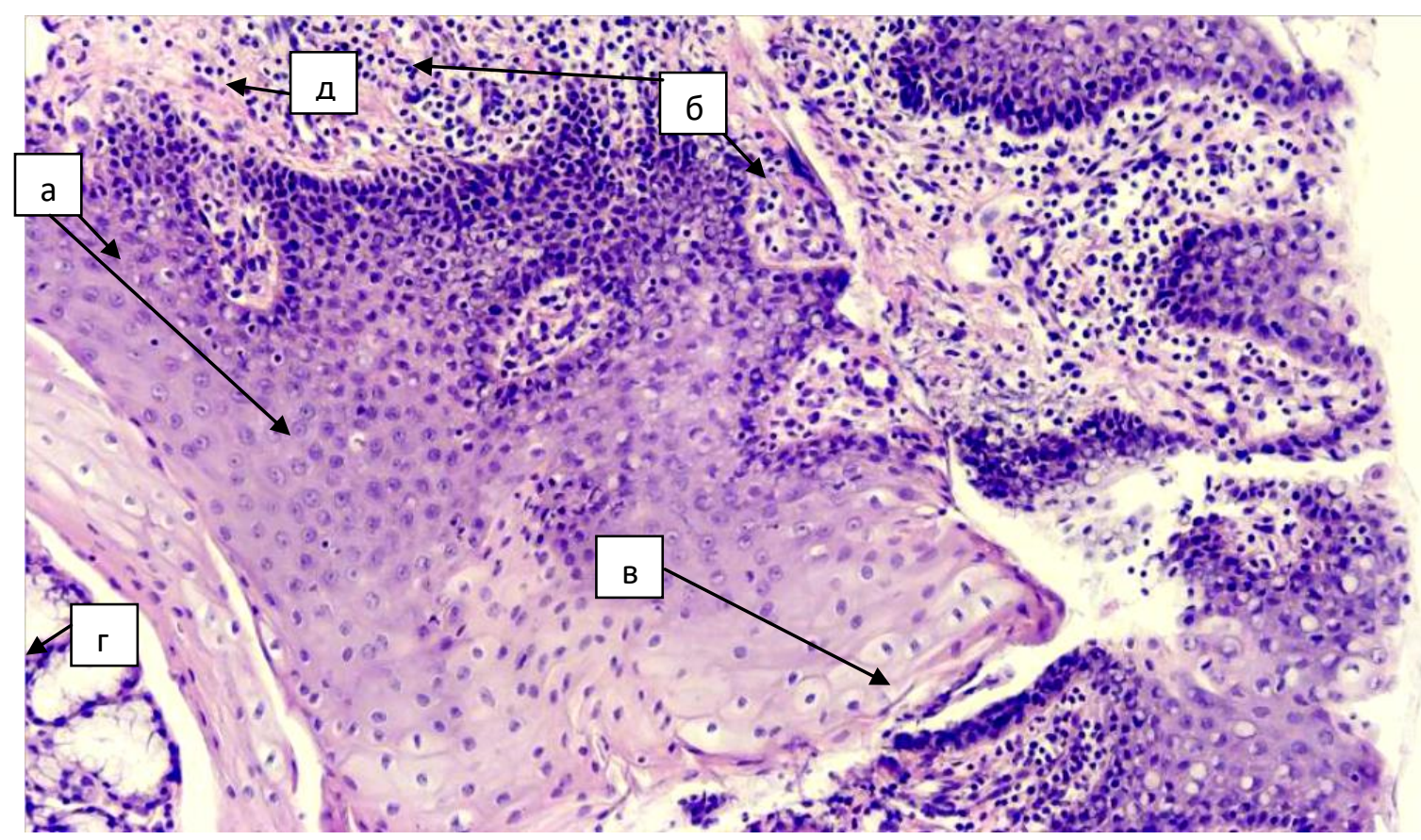

23 расм. Кесма бир қисмининг юзаси кучли ривожланган койлоцитоз ва акантози бўлган етилган ясси эпителийнинг қалинлашган қоплами билан қопланган (a), унинг остида эса ўртача ривожланган лимфоид инфильтрат аниқланади (б). Қопловчи эпителийнинг деструкция сохалари аниқланади (в). Тўқима тубида секретор фаол бўлган сўлак безларининг ўчоқлари жойлашган (г). Стромаси шишли, мушак толалари дистрофияси, томирлар атрофида камгина лимфоид инфилтрати бор (д). Кучли ривожланган койлоцитоз (вирусдан шикастланганлик белгиси), қопловчи ясси эпителийнинг деструкция ўчоқлари мавжуд. Стромал ва периваскуляр лимфоид инфильтрация. (2 гурух) Гематоксилин ва эозин билан бўялган. Кат. об.х 10.0

COVID-19 билан касалланган беморлар юзида йирингли-некротик жарохат билан касалланган 118 та беморнинг биринчи гурухидаги гистологик препаратларда, замбуруғдан шикастланиш шаклдаги морфологик ўзгаришлар узоқ давом этган катарал яллиғланиш ва қон томирлар тромбози туфайли шиллиқ қават эпителийсининг дистрофик ва некротик ўзгариши билан тавсифланди. Касалликнинг барча шаклларида ўчоқли, ўртача ёки диффуз яллиғланиш-хужайрали инфилтрацияси қайд этилиб, бу жараённинг давомийлигини ремиссия ва авж олиш даврлари билан намоён бўлди.

Иккинчи гурух беморларнинг гистологик тадқиқот натижалари бўйича асосан шиллиқ безларнинг кистозли шикастланиши билан тавсифланадиган морфологик ўзгаришларини, хамда қопловчи эпителийнинг ўчоқли ёки диффуз яллиғланишхужайрали инфилтрациясини аниқлаш мумкин.

\section{V. ХУЛОСА.}

Шундай қилиб, юқорида таърифланган COVID-19 билан касалланган беморлар юзида йирингли-некротик жарохатлар, бурун ва бурун олд бўшлиқларининг шиллиқ 
қаватидаги морфологик ўзгаришлар, биринчи гурухда замбуруғли шикастланиш билан таърифланса, иккинчи гурухда яллиғланиш жараёнининг узоқ вақт кечиши билан боғлиқ, шиллиқ ўсимталар ва кистоз хосилалар бўлган эпителий гиперплазияси билан боғлиқ бўлган бурун йўллари архитектоникасининг бузилиши билан, хамда яллиғланиш элементининг борлиги билан, бошқа холларда эса секретининг кўп ажралиши билан, бу эса табиий нафас олишнинг бузилиши билан кечиб давомли гипоксия ривожланишига олиб келади. Юқоридаги барча бузилишлар гипоксия фонида турли тизимлар функцияси пасайиши билан айниқса мия функцияси пасайиши бирга кечади. Морфологик тадқиқотдан олинган натижалар шиллиқ қаватлардаги ўзгаришлар ва клиник белгиларнинг батафсил тавсифини кўрсатиб беради, хамда юздаги нам гангрена - нома ривожланиш хавфини бахолашга, шунингдек касалликнинг қайталанишини олдини олишга имкон беради.

\section{VI. ФОЙДАЛАНИЛГАН АДАБИЁТЛАР РЎЙХАТИ:}

1. Vinay K., Rudramurthy S. M., Dogra S. Emergence of Mucormycosis during COVID-19 pandemic and dermatological manifestations //Indian Dermatology Online Journal. - 2021. - T. 12. - №. 4. - C. 493.

2. Palou E. Y. et al. COVID-19 associated rhino-orbital mucormycosis complicated by gangrenous and bone necrosis - a case report from Honduras //Vaccines. - 2021. - T. 9. №. $8 .-$ C. 826 .

3. Divakar P. K. Fungal taxa responsible for mucormycosis/“black fungus” among COVID-19 patients in India //Journal of Fungi. - 2021. - T. 7. - №. 8. - C. 641.

4. Sen A. Deficient synthesis of melatonin in COVID-19 can impair the resistance of coronavirus patients to mucormycosis //Medical hypotheses. - 2022. - T. 158. - C. 110722.

5. George M. et al. A Rare Case of Rhino Orbito Cerebral Mucor Mycosis Associated with COVID 19 Infection //J Neurol Exp Neurosci. - 2021. - T. 7. - №. 1. - C. 33-37.

6. Varshney V. K. et al. Synchronous Small bowel gangrene with pyelonephritis secondary to mucormycosis: a disastrous complication of COVID-19 pandemic //Cureus. - 2021. - T. 13 . - №. 6.

7. Arora R. et al. Rhino-Orbito-Cerebral-Mucormycosis During the COVID-19 Second Wave in 2021-A Preliminary Report from a Single Hospital //Clinical Ophthalmology (Auckland, NZ). - 2021. - T. 15. - C. 3505.

8. Chakraborty S., Mali K. A morphology-based radiological image segmentation approach for efficient screening of COVID-19 //Biomedical Signal Processing and Control. - 2021. - T. 69. - C. 102800 . 
9. Mitra S., Janweja M., Sengupta A. Post-COVID-19 rhino-orbito-cerebral mucormycosis: a new addition to challenges in pandemic control //European Archives of Oto-RhinoLaryngology. - 2021. - C. 1-6.

10. Song G., Liang G., Liu W. Fungal co-infections associated with global COVID-19 pandemic: a clinical and diagnostic perspective from China //Mycopathologia. - 2020. - C. $1-8$.

11. Ray S. K., Mukherjee S. COVID-19-Associated Mucormycosis, A New Incident in Recent Time: Is An Emerging Disease in The Near Future Impending? //Avicenna Journal of Medicine. -2021.

12. Farias L. A. B. G. et al. COVID-19 associated Mucormycosis (CAM): Should Brazil be on alert? //Revista da Sociedade Brasileira de Medicina Tropical. - 2021. - T. 54.

13. Rodrigues M. G. et al. Loss of an eye to mucormycosis following corticosteroid therapy for COVID-19 //Autopsy and Case Reports. - 2021. - T. 12.

14. Rodrigues M. G. et al. Loss of an eye to mucormycosis following corticosteroid therapy for COVID-19 //Autopsy and Case Reports. - 2021. - T. 12. 